\title{
A diplomacia das cátedras: a política cultural externa alemã e o ensino superior paulista - os casos da USP e da Escola Paulista de Medicina (1934-1942)
}

\author{
The diplomacy of professorships: German cultural foreign policy and higher \\ education in São Paulo: the cases of the University of São Paulo and Escola
} Paulista de Medicina (1934-1942)

Resumo: O artigo trata da participação da diplomacia alemã nas negociações relativas à contratação de professores para a USP, criada em 1934, e para a Escola Paulista de Medicina, do ano anterior. Ao mesmo tempo em que a diplomacia do Terceiro Reich procurou garantir as cátedras para os alemães, a origem judaica dos nomeados para a USP envolveu conflitos e impasses, que não ocorreram com a mesma intensidade no caso do patologista Walter Büngeler, contratado pela escola médica em 1936.

Palavras-chave: diplomacia cultural alemã; USP; Escola Paulista de Medicina.

\begin{abstract}
The article deals with the participation of German diplomacy in negotiations concerning the hiring of professors to USP, established in 1934, and to São Paulo's Medical School (Escola Paulista de Medicina), created a year earlier. The Third Reich's diplomacy sought to ensure the professorship to the Germans, but at the same time, the Jew ascendancy of those appointed to USP originated conflicts and impasses, that were not so intensive in the case of the pathologist hired to the Medical School in 1936, Walter Büngeler.
\end{abstract}

Keywords: German cultural diplomacy; USP; Escola Paulista de Medicina

A literatura memorialística e historiográfica que trata da criação da USP menciona a contratação de professores estrangeiros como aspecto fundamental na construção e consolidação da Faculdade de Filosofia, Ciências e Letras, que atuou como espinha dorsal da universidade,

\footnotetext{
* Pós-Doutorando - Departamento de História - Faculdade de Filosofia, Letras e Ciências Humanas - USP Universidade de São Paulo, Av. Professor Luciano Gualberto, 315, Cidade Universitária, CEP 05508-900, São Paulo SP. Artigo desenvolvido com financiamento da FAPESP. E-mail: andrefelipe@,usp.br
} 
estabelecida em janeiro de 1934 por decreto do interventor Armando Salles de Oliveira. ${ }^{1}$ Em termos gerais, essa literatura apresenta a nomeação de professores estrangeiros - os quais não haveria no Brasil em quantidade e perfil adequados ${ }^{2}$ - como fruto da necessidade de atrair docentes para a formação de profissionais nas áreas das ciências básicas. Professores de prestígio reconhecido em disciplinas como matemática, física, geografia, literatura e história natural garantiriam a excelência da formação oferecida pela nova universidade. As diplomacias da França e da Itália logo se mobilizaram a fim de favorecer a contratação de professores que atuassem no Brasil como representantes dos respectivos países. Eles atenderiam aos interesses da política cultural externa, orquestrada em Roma e Paris, na medida em que promoveriam a cultura de seus locais de origem no contato com os estudantes e colegas. Menos conhecido é o envolvimento da diplomacia alemã na contratação dos três professores que vieram a integrar o corpo docente da USP: Felix Rawitscher, Heinrich Rheinboldt e Ernst Bresslau, catedráticos de botânica, de química e de zoologia, respectivamente. Se no caso da França sabe-se das relações do "grupo do Estado" com Georges Dumas, principal articulador da política cultural francesa para o Brasil e demais países da América Latina (PETITJEAN, 1996, 1996b; SUPPO, 2000), no caso da Alemanha há poucas referências sobre os canais e as dinâmicas que atuaram na nomeação dos professores acima mencionados.

A participação da diplomacia alemã na criação da USP é particularmente interessante por envolver cientistas de origem judaica, num momento em que o governo nazista os excluía de seus quadros. A Lei para Restauração do Serviço Público Profissional, de 07 de abril de 1933, acarretou enorme êxodo de intelectuais judeus alemães, com consequências em termos sociais, econômicos, políticos e científicos, além do impacto dramático nas trajetórias pessoais e familiares. Durante o ano de 1933, 37 mil judeus deixaram a Alemanha. Mil e duzentos professores de origem judaica foram demitidos de seus postos acadêmicos (FRIEDLÄNDER, 2012, p. 87; p. 102).

A ascendência judaica dos professores nomeados para a USP trouxe tensões particulares com a diplomacia de Berlim, que se tornaram mais evidentes e delicadas com a sucessão de Ernst Bresslau, que morreu quase um ano depois de ter chegado a São Paulo. Em seu lugar, foi contratado o zoólogo Ernst Marcus, também de origem judaica, que atuou por longos anos na capital paulista e contribuiu de forma decisiva para a construção de uma tradição científica em sua especialidade. ${ }^{3}$

Pouco tempo depois, os oficiais da Wilhelmstrasse, endereço da chancelaria alemã, participariam novamente da nomeação de um professor para o ensino superior de São Paulo; desta vez, um anátomo-patologista para a Escola Paulista de Medicina, o alemão Walter Büngeler, que entre 1936 e 1942 foi catedrático de anatomia patológica da referida escola. 
O objetivo do presente trabalho é apresentar as tensões e impasses das negociações que levaram às nomeações de Büngeler e dos professores alemães da Faculdade de Filosofia, Ciências e Letras da USP. Com isso, pretende-se contribuir para a compreensão da política cultural da Alemanha nazista direcionada ao Brasil, trazendo à cena alguns personagens que atuaram como pontos de apoio dessa política, as disputas entre as diplomacias de Alemanha, França e Itália por nichos de influência cultural e seu impacto na constituição das duas instituições de ensino superior em São Paulo nos anos 1930. As contradições e conflitos da política de perseguição aos judeus na Alemanha repercutiram nas redes envolvidas na política cultural alemã no Brasil. Enquanto os professores italianos e franceses obtiveram vantagens de seus respectivos governos ao se apresentarem como missionários da política cultural externa, os alemães não contaram com as mesmas regalias, uma vez que a origem judaica tornou problemática sua condição de representantes da nação alemã num momento em que os judeus foram considerados excluídos do ideal da "Volksgemeinschaft" (comunidade nacional).

\section{A diplomacia cultural alemã e a criação da USP}

A criação da Universidade de São Paulo, em 25 de janeiro de 1934, foi resultado da mobilização de um grupo de intelectuais que gravitava em torno do diretor do jornal $O$ Estado de São Paulo, Júlio de Mesquita Filho. De acordo com a literatura que trata deste evento, ele obedeceu a imperativos de ordem política, cultural e científica. A nova universidade teria, por um lado, a função de garantir a hegemonia cultural de São Paulo depois da derrota na revolução de 1932, formando novas lideranças capazes de assegurar projeção política ao estado e contrabalançar as tendências centralistas do governo de Getúlio Vargas. Por outro lado, os fundadores da USP tinham por intenção investir na formação de docentes para o ensino secundário, proporcionar treinamento aos interessados em seguir carreira científica e atuar como espaço institucional para cultivo de uma "ciência desinteressada", ou seja, livre das injunções que as limitavam a suas aplicações práticas. ${ }^{4}$

O prestigiado matemático e engenheiro Theodoro Ramos, professor da Escola Politécnica de São Paulo, foi nomeado diretor da Faculdade de Filosofia, Ciências e Letras, que atuou como núcleo aglutinador da nova universidade. ${ }^{5}$ Em fins de fevereiro de 1934, Ramos partiu para a Europa, encarregado de contratar professores estrangeiros e analisar a estrutura de funcionamento das universidades. Seu primeiro destino foi a Itália, onde desembarcou em 13 de março de 1934. Lá, estabeleceu contato com ministros, oficiais do governo fascista ligados à diplomacia e reitores de universidades (O ESTADO DE SÃO PAULO, 1934). Entre eles, esteve com o diretor do órgão que cuidava dos interesses dos italianos no exterior, além de ter sido recebido pelo próprio 
Mussolini (PETITJEAN, 1996, p. 263). As negociações com o governo italiano resultaram na contratação do matemático Luigi Fantappié, do físico de origem russa Gleb Wataghin e do professor de literatura italiana Francisco Piccolo.

Um dos idealizadores da USP, Júlio de Mesquita Filho (1969), afirma que a competição entre os franceses e italianos por influência na vida cultural e científica de São Paulo foi o pano de fundo da contratação dos professores estrangeiros. Em análise da documentação da diplomacia francesa, Petitjean (1996) confirma este aspecto: satisfeitos por Ramos ter contratado apenas três italianos, em vez dos cinco previstos originalmente, os franceses movimentaram-se para obter o maior número possível de cadeiras. Em Paris, foi oferecido a Ramos um almoço oficial, com a presença de ministros de Estado, da Educação, do chefe de gabinete da chancelaria francesa e de representantes do mundo acadêmico, entre eles, Georges Dumas (O ESTADO DE SÃO PAULO, 1934). Amigo pessoal de Júlio de Mesquita Filho e ponta-de-lança da diplomacia cultural francesa no Brasil, Dumas foi um dos principais responsáveis por indicar os nomes que ocupariam as cadeiras na recém-criada Faculdade de Filosofia, Ciências e Letras. O recrutamento foi mais difícil do que o previsto inicialmente, não obstante as garantias oferecidas pelo governo francês (complemento de salários, pagamento de viagens de ida e volta, sem incluir financiamento de férias na França) (PETITJEAN, 1996, p. 266). No final das contas, seis professores franceses foram contratados por Ramos: Émile Coornaert, para a cadeira de história da civilização; Pierre Deffontaines, para a de geografia; Paul Arbousse-Bastide, para a de sociologia; Robert Garric, para a de literatura francesa; e Michel Berveiller, para a de literatura greco-latina, além de Étienne Borne, para a de filosofia e psicologia. Os franceses conseguiram ocupar o dobro do número de cadeiras conquistadas pelos italianos, mas os esforços de Dumas não foram suficientes para obter as cátedras de zoologia e botânica, previstas para alemães (PETITJEAN, 1996). Nota-se, então, que Ramos partiu para a Europa com uma lista de sugestões que seriam oferecidas aos estrangeiros, com uma divisão de acordo com a nacionalidade.

Em leitura retrospectiva da criação da USP, o jornalista Paulo Duarte (1976) afirma que as disciplinas ligadas à "formação do espírito" - as humanidades e ciências sociais - ficariam reservadas aos franceses, pois ele e os demais idealizadores da nova universidade temiam que elas caíssem nas mãos de representantes de nacionalidades de inclinação totalitária, como eram Itália e Alemanha naqueles anos. Júlio de Mesquita Filho (1969, p. 92) também alude a esse aspecto, atribuindo a predileção pelos franceses nas cadeiras "que tocavam a formação moral” a seu espírito democrático e liberal, o que coincidiria com a marca que ele e os demais fundadores queriam imprimir ao novo centro de ensino e pesquisa. ${ }^{6}$ As cátedras de ciências naturais caberiam, além dos italianos, aos alemães, reconhecidos pela inclinação à pesquisa científica e tecnológica. 
Alguns personagens que participaram ou testemunharam a fundação da USP, como seu futuro professor Paulo Sawaya, ${ }^{7}$ relatam que as sugestões dos alemães que ocupariam as cátedras foram feitas pelo microbiologista e patologista Henrique da Rocha Lima, diretor do Instituto Biológico de Defesa Agrícola e Animal, criado em São Paulo em 1927. Além de pertencer à primeira geração de médicos que participou com Oswaldo Cruz da criação do Instituto de Manguinhos no Rio de Janeiro, Rocha Lima havia trabalhado por 18 anos (entre 1909 e 1927) no Instituto de Doenças Marítimas e Tropicais de Hamburgo. Seu retorno ao Brasil coincidiu com a fundação, pelo ex-colega de Manguinhos, Arthur Neiva, de uma instituição destinada à pesquisa e à defesa sanitária da agricultura e pecuária. ${ }^{8}$ Inicialmente, Rocha Lima dirigiu a divisão animal, mas em 1933 assumiu a direção geral do chamado Instituto Biológico de São Paulo, substituindo Neiva, que se afastou de São Paulo em decorrência das turbulências políticas da revolução de $1932 .{ }^{9}$

No período em que esteve na Alemanha, Rocha Lima foi um dos mais ativos incentivadores do intercâmbio intelectual germano-brasileiro (SILVA, 2011). Esse esforço assumiu nova conotação depois da Primeira Guerra e do Tratado de Versalhes, cujas cláusulas levaram os alemães a investir mais intensamente no planejamento e execução de uma política cultural externa. A azeitada máquina de diplomacia cultural posta em ação pelos franceses atuou, ao mesmo tempo, como modelo e principal antagonista das iniciativas endereçadas pelos alemães à América Latina. Rocha Lima encaminhou e orientou intelectuais alemães e brasileiros nos dois sentidos, cooperou com os diplomatas alemães na formulação de uma política cultural para o Brasil e defendeu publicamente a importância dos laços entre os dois países para o desenvolvimento científico de sua pátria de origem. Mesmo depois de se estabelecer em São Paulo, o cientista, prestigiado sobretudo pela identificação do agente causador do tifo exantemático, continuou a promover as relações científicas Brasil-Alemanha (SILVA, 2011). O conhecimento que tinha do meio científico alemão habilitava-o a indicar os nomes que ocupariam as cadeiras de ciências naturais da universidade que então surgia.

Como diretor do Instituto Biológico, Rocha Lima fez parte da primeira composição do Conselho Universitário da USP. ${ }^{10}$ Em suas memórias, Paulo Duarte (1976, p. 68) recorda que foi o responsável pela indicação de Rocha Lima para o grupo envolvido na criação da USP, a despeito da oposição de Júlio de Mesquita Filho, que o considerava “alemão demais". No entanto, a correspondência pessoal do diretor do Biológico atesta sua proximidade com o líder do jornal $O$ Estado, inclusive, ele frequentava sua fazenda no interior de São Paulo e colaborava com a redação do matutino. ${ }^{11}$ A germanofilia de Rocha Lima parece, dessa forma, não ter ocasionado maiores reservas por parte do francófilo Mesquita Filho, problematizando-se de certo modo a afirmação de Duarte, que busca nas memórias reaver o relevo que teria alcançado na criação da USP. 
A correspondência de Rocha Lima confirma a indicação de apenas um dos nomes que vieram a fazer parte da Faculdade de Filosofia: o do zoólogo Ernst Bresslau, que já estivera no Brasil entre 1913 e 1914 e, novamente, em 1929, ocasião em que teve o apoio do diretor do Biológico. ${ }^{12}$ Em 26 de fevereiro de 1934, Rocha Lima escreveu ao médico Fritz Munk, que atuava em Berlim e de quem se tornou amigo na Primeira Guerra durante as pesquisas médicas que ambos realizavam na Polônia, noticiando que Theodoro Ramos -"que considero muito em todos os sentidos e goza de grande renome aqui", salientou - passaria pela Alemanha com o objetivo de contratar professores para a recém-criada USP. Sugeriu que Munk o ajudasse na indicação de pessoas dispostas a emigrar para o Brasil, principalmente “intelectuais não-arianos ou arianos não bem vistos". Entre eles, citou o zoólogo de origem judaica e diretor do Instituto de Zoologia da Universidade de Colônia, Ernst Bresslau, "porque já esteve várias vezes no Brasil e deixou aqui uma impressão muito boa", argumentou. ${ }^{13}$ Os nomes do botânico Rawitscher e do químico Rheinboldt não aparecem na carta, não sendo possível saber se a indicação deles partiu, de fato, de Rocha Lima, se foi uma sugestão do próprio Munk ou se envolveu outros canais que não aparecem nas fontes consultadas, não passando, portanto, pelo diretor do Biológico. Notícia de O Estado de São Paulo de 30 de maio de 1934 descreve o percurso de Theodoro Ramos pela Alemanha, onde visitou os institutos de zoologia e botânica da Universidade de Colônia e o instituto de química da Universidade de Bonn, em que atuava Henrich Rheinboldt.

Em junho de 1934, Rocha Lima escreveu novamente a Munk comentando a nomeação dos professores alemães: "Três professores foram convidados para a recém-criada USP [...] Embora não sejam arianos, acredito que não poderíamos encontrar melhores representantes da autêntica ciência alemã". ${ }^{14}$ Esse comentário remete às motivações da orientação de Rocha Lima a Munk no sentido de procurar "intelectuais não-arianos ou arianos não bem vistos". Teria sido uma iniciativa dele próprio ou foi uma indicação de Mesquita e dos demais membros do grupo envolvido na criação da USP ${ }^{15}$ Tanto num caso como no outro, teria sido uma ação impulsionada por razões de ordem humanitária, uma vez que a perseguição aos judeus na Alemanha já era de conhecimento da imprensa internacional, ou por motivos mais pragmáticos, por envolver profissionais que de qualquer forma já procuravam abandonar seu país e, em face disso, estavam mais inclinados a aceitar as condições oferecidas pelo governo de São Paulo? As fontes examinadas não autorizam qualquer afirmação conclusiva a esse respeito.

Petitjean (1996, p. 269) sublinha que a faixa etária dos professores alemães era maior que a dos colegas franceses contratados para a USP. Os alemães apresentaram, em geral, trajetória científica mais bem estabelecida em termos de produção intelectual e reconhecimento. Os franceses eram, em sua maioria, jovens e iniciantes na carreira acadêmica. 
Heinrich Rheinboldt tinha 43 anos quando foi nomeado para a cadeira de química da USP. De acordo com Paschoal Senise, ao chegar a São Paulo, em junho de 1934, ele já era conhecido não apenas pela ampla produção científica, mas também por ser autor do manual "Chemische Unterrichtsversuche" (SENISE, 2006). ${ }^{16}$ Inicialmente assumiu as aulas de química orgânica, inorgânica e analítica, as quais só se iniciaram no ano seguinte devido à falta de instalações adequadas para os experimentos. Rheinboldt teve como assistente o alemão residente em São Paulo Herbert Stettiner. Ele sugeriu a nomeação de um professor para auxiliá-lo nas tarefas didáticas e participar das atividades de pesquisa. O escolhido foi o químico Heinrich Hauptmann, ex-professor da Universidade de Göttingen, ${ }^{17}$ mas que se encontrava em Genebra desde que fora demitido do posto em virtude da origem judaica. ${ }^{18}$ Chegou a São Paulo em fevereiro de 1935 e desempenhou importante papel na edificação de uma tradição de estudos em química na USP (SENISE, 2006, p. 20). ${ }^{19}$

Felix Kurt Rawitscher chegou a São Paulo com 44 anos. ${ }^{20}$ Era conhecido por seus trabalhos iniciais no campo da botânica e da ecologia. Segundo a memorialística que trata de sua atuação profissional, reunia vasto conhecimento nos campos da anatomia e morfologia vegetal.

Bresslau, o mais velho dos três, foi quem tomou a frente nas negociações com o governo de São Paulo e com a diplomacia alemã. Representando os outros dois colegas, comunicou à Divisão Cultural do Ministério das Relações Exteriores em 22 de maio de 1934 que os três haviam fechado contrato há dez dias com a USP. A Divisão Cultural havia sido criada em 1920 com a função de coordenar a política cultural externa alemã, um dos poucos domínios que não estavam limitados pelas cláusulas de Versalhes. Uma de suas divisões encarregou-se da difusão da literatura alemã, institutos alemães no exterior, congressos e acordos científicos, intercâmbio de literatura científica, circulação de intelectuais, tanto de alemães no exterior quanto de estrangeiros na Alemanha, aconselhamento de acadêmicos alemães no estrangeiro e filmes. ${ }^{21}$

A nomeação de professores alemães para universidades no exterior foi assunto acompanhado de perto pelos agentes da Divisão Cultural. Na referida carta àquele departamento, Bresslau salientou que Rheinboldt havia firmado o contrato sem reservas. Rawitscher, com a condição de que fosse imediatamente licenciado pelo governo alemão, e ele próprio, com a premissa de que só confirmaria o contrato no final de 1934, depois de seis meses em São Paulo. Comunicou estar a par da informação de que os governos italiano e francês haviam assegurado uma série de garantias para os professores nomeados para a USP. De fato, o governo italiano se encarregara das passagens de ida e volta e de um complemento salarial aos acadêmicos contratados, informação que Theodoro Ramos havia confirmado uma semana antes com o embaixador brasileiro em Roma. ${ }^{22}$ Além desses benefícios, os franceses conseguiram ainda que metade do salário no 
Brasil fosse pago em francos (PETITJEAN, 1996, p. 266). Bresslau pediu a Ramos que procurasse obter vantagens semelhantes do Reich por meios diplomáticos, mas o brasileiro afirmou não poder ir até Berlim para negociar com as autoridades. ${ }^{23}$

O caminho alternativo que Ramos encontrou para atuar em favor dos alemães ocorreu por intermédio de Rocha Lima: a pedido de Ramos, este apresentou a demanda ao cônsul alemão em São Paulo, que acenou para a possibilidade das autoridades de Berlim oferecerem condições semelhantes às concedidas por França e Itália. "Faço votos para que o ilustre amigo, bem como os professores Rawitscher e Rheinboldt, obtenham do governo alemão facilidades a fim de que possam lecionar na Universidade de São Paulo em breve", escreveu Ramos a Bresslau. O zoólogo, no entanto, dispensou as intermediações, dirigindo-se diretamente às autoridades diplomáticas para obter os benefícios. Justificou que ele e os demais contratados deveriam partir logo para o Brasil, pois o atraso acarretava o risco de as cadeiras serem ocupadas por franceses ou italianos, "que se esforçam intensamente, como é sabido, pelas cátedras em questão.” E acrescentou: “Através de tais esforços eles conseguiram, agora, que a cadeira de geologia e mineralogia, que originalmente seria ocupada por um alemão, fosse concedida a um professor italiano, por pressão do governo da Itália". ${ }^{24}$ Bresslau argumentou ainda que os professores alemães, além da inferioridade numérica em relação aos franceses e italianos, encontravam-se em desvantagem financeira por não dispor dos subsídios do governo de seu país. Essa falta de "ajuda eficaz e apoio completo" por parte do Reich poderia dificultar o grande volume de pedidos de livros, equipamentos e material de ensino que eles, como diretores dos recém-criados institutos de ciências naturais, pretendiam endereçar à Alemanha. O zoólogo não só explorava a rivalidade entre os países europeus para persuadir o governo alemão a lhes conceder vantagens como insinuava um possível ônus financeiro ocasionado pela falta de apoio oficial.

$\mathrm{Na}$ tentativa de obter essa chancela, Bresslau pediu que as representações alemãs no Brasil fossem comunicadas de que a nomeação deles para a USP tinha anuência do governo, de modo que figuravam como representantes oficiais da Alemanha. Tal pedido não era trivial, num momento em que muitos judeus fugiam da perseguição nazista. Entre 1933 e 1934 o ingresso de judeus alemães no Brasil subiu de 363 para 835 pessoas (SCHPUN, 2011, p. 72). Na qualidade de acadêmico, Bresslau sentiu-se no direito de reivindicar garantias que o distinguissem, assim como Rheinboldt e Rawitscher, dos demais judeus que procuravam as representações diplomáticas na tentativa de obter um visto para emigrar. O zoólogo solicitou ainda que autoridades financeiras fossem rapidamente certificadas de que a partida deles atendia aos interesses do Estado alemão. Certamente, dessa forma procurava minimizar o risco de confisco de bens ao qual estavam submetidos os judeus que deixavam a Alemanha. ${ }^{25}$ Reivindicou ainda que Rawitscher fosse imediatamente licenciado pelo 
Ministério da Educação de Baden, ao qual estava subordinado, e que o Ministério da Ciência e Educação autorizasse sua mudança de residência para São Paulo a fim de continuar recebendo sua aposentadoria. Ele reforçou também o pedido de que o Reich garantisse as mesmas salvaguardas financeiras asseguradas por Roma e Paris.

O governo alemão não autorizou a concessão de benefícios financeiros aos professores contratados para a USP, justificando que eles não eram autênticos representantes dos interesses alemães no estrangeiro por se tratarem de "não-arianos". O pedido de licença de Rawitscher foi deferido em 06 de junho de 1934. Rheinboldt, como vimos, firmara o contrato sem exigir contrapartidas. Mais problemático foi o pedido de Bresslau de continuar recebendo sua aposentadoria do governo alemão depois da mudança para São Paulo, aonde chegou, junto com os demais, em 30 de junho de 1934. Já na capital paulista, Bresslau tentou obter seus provimentos, acionando para isso a representação diplomática local. Em julho de 1934, o consulado de São Paulo encaminhou a solicitação a Berlim, acrescentando que a nomeação para as cátedras havia sido bastante disputada pelos franceses e italianos devido "às possibilidades de propaganda e do seu possível efeito em favor dos interesses de seus países”. Por conta disso, França e Itália haviam garantido a continuação do pagamento do salário que os professores contratados recebiam em seus locais de origem. Seria insensato e prejudicial aos interesses alemães - argumentou o cônsul - se o Reich não concedesse facilidades financeiras para que Bresslau atuasse em favor da Alemanha. "Eu obviamente vou ficar de olhos abertos nele e relatarei imediatamente, caso eu fique sabendo de qualquer coisa que porventura possa mudar minha opinião", afiançou o cônsul. ${ }^{26}$

Em outubro de 1934, o Ministério da Ciência e Educação indeferiu o pedido de Bresslau, alegando que ele só poderia continuar a receber sua aposentadoria decorrente da sua demissão caso se estabelecesse fora do território alemão em caráter permanente. ${ }^{27} \mathrm{O}$ contrato com a USP tinha duração de três anos, podendo ou não ser prolongado, o que excluía Bresslau do seu direito. Junto à notificação do Ministério da Ciência, transmitido à curadoria da Universidade de Colônia e ao Ministério das Relações Exteriores, foi anexada cópia de uma carta do diretor do departamento de pesquisa e ensino superior do Ministério da Ciência e Educação, professor Bachér, na qual manifestou desacordo com a opinião do cônsul alemão em São Paulo: "Contrariamente às afirmações do consulado alemão em São Paulo, defendo a opinião de que a maior parte dos professores demitidos em decorrência da Lei de Restauração do Serviço Público não vai para o exterior na qualidade de professores alemães" (grifos no original). Dessa forma não se poderia esperar - acrescentou - que Bresslau, enquanto "não-ariano", "represente de forma sincera os interesses alemães no exterior." Ademais, o câmbio desfavorável recomendava negar a continuidade do pagamento de seus vencimentos no Brasil. ${ }^{28}$ 
O zoólogo não desistiu. Novamente o consulado alemão em São Paulo defendeu seus interesses junto aos burocratas de Berlim. No ofício, o cônsul argumentou que os três professores alemães nomeados para as cadeiras da USP poderiam ser muito úteis ao Terceiro Reich, "como também podem nos prejudicar muito", ressaltou. Novamente lembrou a ambição das chancelarias francesa e italiana pelas cátedras e as mesuras com que cercaram Theodoro Ramos quando visitou os dois países. Lamentou que nem Ramos nem o governo paulista tivessem procurado as representações alemãs para indicação de nomes apropriados para ocupar as cadeiras que ainda ofereciam perspectivas de importação de literatura e equipamentos científicos da Alemanha, os quais, segundo o cônsul, faltavam completamente no Brasil. E acrescentou:

Sob tais circunstâncias iríamos contra nossos próprios interesses se não apoiássemos os professores em suas questões pessoais e não levássemos em conta, na medida de nossas possibilidades, as justas reivindicações apresentadas por eles. Nossas possibilidades de propaganda são bastante limitadas aqui, uma vez que a imprensa local é quase completamente influenciada pela agência francesa Havas e os professores das escolas superiores, predominantemente de orientação francófila. Os professores citados [os alemães] oferecem possibilidades que não podemos dispensar. Vista pelos olhos daqui, a ocupação das referidas cátedras por professores alemães significa, sem sombra de dúvida, um sinal de reverência à ciência alemã. $\mathrm{O}$ fato de que os professores não são de origem ariana (Rawitscher) ou não são arianos puros (Bresslau, Rheinboldt) é, em si, bastante lastimável. Mas tal fato não pode, diante das circunstâncias que temos diante de nossos olhos, prevenir-nos de servir aos nossos próprios interesses. Por tudo isso permito-me pedir obedientemente ao Ministério das Relações Exteriores, que atue energicamente em favor do pedido do professor Bresslau. ${ }^{29}$

Apesar do valioso apoio e intermediação do consulado, como pudemos notar acima, Bresslau não desistiu de defender diretamente seus interesses junto às autoridades alemãs. Mobilizou o Ministério das Relações Exteriores, o departamento de Finanças e a curadoria da Universidade de Colônia para conseguir receber sua aposentadoria em São Paulo. ${ }^{30}$ Tentou ainda a liberação de parte do dinheiro de sua conta pessoal na Alemanha, bloqueado pelo governo, para custeio das despesas de viagem da mulher e dos filhos. Ao departamento de finanças da Renânia do Norte-Vestefália, o zoólogo reforçou sua condição de representante da cultura, dos interesses e da ciência alemã, procurando distinguir-se dos “meros” imigrantes judeus que deixavam o país:

Eu não vim para o Brasil para emigrar da Alemanha. Pelo contrário, vim com dois colegas alemães, ao lado de seis professores franceses e quatro italianos, por ter sido convidado pela recém-criada Faculdade de Filosofia e Ciências Naturais da Universidade de São Paulo, convite que eu aceitei com aprovação do governo do Reich. Não estou aqui na condição de um simples emigrante qualquer; leciono na universidade local como representante da ciência alemã, como decretou o Ministério das Relações Exteriores em despacho de número VI W4650, de 26 de maio de 1934. Nesse momento, minha atividade, como a de meus colegas, é de particular importância para os interesses alemães (grifos no original). ${ }^{31}$ 
Um dos argumentos utilizados por Bresslau para conseguir o desbloqueio de sua conta e continuar a receber sua aposentadoria era o de que aquele dinheiro era importante para ele adquirir seus livros e pagar as associações científicas às quais pertencia. ${ }^{32}$ Para comprovar a relevância da atuação de Bresslau em favor da diplomacia cultural alemã, sua esposa enviou a Berlim recorte de O Estado de São Paulo de 22 de novembro de 1934 que noticiava a repercussão da conferência do zoólogo na Academia Brasileira de Ciências, no Rio de Janeiro, da qual tornou-se membro. ${ }^{33}$ Bresslau retomou o argumento do interesse que havia na importação de literatura científica e equipamentos, os quais preferia que fossem adquiridos na Alemanha. "Cada livro alemão é o melhor meio de propaganda cultural que pode existir aqui”, declarou o professor, pois permitia contrabalançar a predominância de livros franceses e italianos. ${ }^{34}$ Por meio do Ministério das Relações Exteriores, o zoólogo negociou com a firma Zeiss a importação subsidiada de instrumentos ópticos a fim de cobrir a concorrência norte-americana, que oferecia equipamentos mais baratos. ${ }^{35}$

No final de 1934 ainda prosseguiam os trâmites para a aprovação do pagamento da aposentadoria de Bresslau em São Paulo. Outro intermediário entrou na negociação: o colega dos tempos da Universidade de Estrasburgo, Martin Hahn, que atestou aos diplomatas a boa postura de Bresslau perante a nação alemã. Acrescentou que a esposa do professor descendia de notável família de tronco "ariano", que lutara "de forma notável" pela causa da "germanidade" (Deutschtum) na Alsácia. Sugeriu que Bresslau fosse favorecido, nem que fosse para provisoriamente "segurar o posto" para a Alemanha até ser sucedido mais tarde por um "alemão ariano". 36

Os esforços de Bresslau foram bem-sucedidos: em janeiro de 1935 foi autorizada a continuação do pagamento de sua aposentadoria em São Paulo. ${ }^{37}$ Mas em maio de 1935 ele morreu repentinamente, restando à esposa atuar junto às autoridades alemãs para continuar recebendo a pensão do marido. Novamente ela enviou à chancelaria na Wilhelmstraße recortes de jornais brasileiros que relatavam as homenagens oficiais a Bresslau como prova da estima que o marido gozara no curto tempo vivido em São Paulo e de seu trabalho em favor da cultura e ciência alemãs. ${ }^{38}$ Ao Ministério das Relações Exteriores, Luise Bresslau fez uma afirmação que era de grande interesse para a diplomacia cultural do Terceiro Reich: que os alunos de seu marido manifestavam o desejo "de continuarem a ser instruídos nos moldes da ciência alemã". 39 Novamente os órgãos ligados à diplomacia, ao Partido Nazista e personalidades envolvidas na política cultural externa se mobilizariam para garantir que um alemão ocupasse a cadeira de zoologia da USP. 


\section{A diplomacia alemã e a sucessão de Bresslau}

Em 21 de maio de 1935, o cônsul alemão em São Paulo comunicou Berlim da morte de Bresslau e da intenção de sua esposa e filhos de permanecer no Brasil. ${ }^{40}$ A Organização Estrangeira do Partido Nazista, que também desempenhava funções ligadas à política externa, não sem conflitos com os círculos diplomáticos, comunicou ao Ministério da Ciência que estava previsto um sucessor alemão para a cadeira, o qual deveria ser rapidamente apontado a fim de evitar que o posto fosse ocupado por membro de outra nacionalidade. ${ }^{41}$ Já o cônsul alemão em São Paulo reportou que a sucessão do zoólogo ainda não era assunto resolvido na USP e que se manteria informado com membros da universidade, de modo a assegurar a nomeação de um alemão. ${ }^{42}$

Logo começaram a aparecer os candidatos. Anton Koegel, diretor do Instituto de Zoologia da Escola Técnica de Munique, manifestou interesse pela cadeira na USP, apresentando como credenciais sua experiência no estudo de pragas tropicais e como campos de atuação "biologia geral e zoologia, anatomia e fisiologia comparadas, fisiologia animal e parasitologia". ${ }^{43}$ Henrique da Rocha Lima consultou o colega do Instituto de Doenças Tropicais de Hamburgo, Martin Mayer, pedindo sugestões de zoólogos de projeção científica e indagando sobre alguns nomes propostos no consulado alemão. Mayer indicou o entomologista de origem judaica Otto Hecht, que já havia pedido a Rocha Lima um posto no Instituto Biológico depois de ter sido demitido do Instituto de Hamburgo. ${ }^{44}$ Da carta de Mayer, deduz-se que outro nome em questão era o do biólogo Victor Jollos, a quem considerava muito unilateral na abordagem das temáticas científicas, além de superestimar o valor de seus trabalhos. ${ }^{45}$

Em setembro, o consulado de São Paulo comunicou que a USP estava negociando com Leopold von Ubisch, ${ }^{46}$ da Universidade de Münster, e Ernst Marcus, da Universidade de Berlim, ambos judeus. O cônsul indagou se havia alguma objeção por parte do Ministério da Ciência em relação aos nomes indicados. Caso estivessem envolvidos com propaganda antialemã, sobretudo von Ubisch, que se encontrava nos Estados Unidos, sua nomeação para a cátedra deveria ser impedida, de modo a evitar que o contratado atuasse de forma contrária aos interesses alemães. "Interessante seria averiguar de onde parte a indicação dos nomes dos professores aqui mencionados, e dos que foram apresentados antes, e investigar sobre quais caminhos estão sendo feitas as negociações", interpelou o cônsul. Especulou que a loja maçônica estivesse por trás das indicações, "o que é sugerido pelo fato de que apenas professores não-arianos parecem se interessar pelos postos importantes que surgem aqui", emendou. ${ }^{47}$ 
O Ministério da Ciência manifestou preferência por Koegel. Caso este não fosse aceito, preferia Ernst Marcus a von Ubisch, muito embora o primeiro fosse "Volljuden", enquanto que o segundo era apenas "meio-judeu" (Halbjuden). ${ }^{48}$ Ambos haviam lutado pela Alemanha durante a Primeira Guerra. ${ }^{49} \mathrm{O}$ diretor da Organização Estrangeira do Partido Nazista também sugeriu a contratação de Koegel; a origem judaica desfavorecia a atuação dos outros dois em favor da Alemanha, ainda que não estivessem associados à propaganda antigermânica. Num lugar de "marcante influência alemã" como São Paulo seria de grande valor a nomeação de um professor "ariano", capaz de defender os interesses alemães de forma duradoura e engajar-se ativamente na política de fomento da "germanidade", acrescentou o oficial nazista. ${ }^{50}$

O cônsul em São Paulo transmitiu as indicações ao governo: manifestou a preferência por Koegel, mas ressaltou que não havia nenhuma objeção caso as negociações com Marcus já estivessem adiantadas. No entanto Félix Rawitscher comunicou ao consulado que nenhum dos dois nomes apontados parecia conveniente para a USP. Segundo ele, o nome de Koegel fora recusado pela secretaria da Educação por tratar-se de um desconhecido. Rawitscher reportou que o governo paulista e a universidade estavam mais interessados em contratar Richard Goldschmidt, diretor do Instituto Kaiser-Wilhelm de Biologia, visto como mais apto a conduzir os planos de expansão que se tinham para o instituto de zoologia. ${ }^{51} \mathrm{O}$ Ministério da Ciência concordou com a eventual nomeação de Goldschmidt e ressaltou não ter nada contra a atuação e possível contratação de Marcus. ${ }^{52}$ Mas Goldschmidt, também judeu, já estava negociando sua ida para os Estados Unidos. Finalmente, em fevereiro de 1936, foi comunicada ao consulado alemão de São Paulo a nomeação de Ernst Marcus para a cadeira de zoologia. ${ }^{53}$ Em agradecimento pela anuência do governo alemão para a contratação de Marcus, a direção da Faculdade de Filosofia, Ciências e Letras manifestou "esperança de que o governo alemão conceda todas as facilidades para que Marcus assuma a cadeira de zoologia ainda esse ano".

Muito embora a Organização Estrangeira do Partido Nazista tivesse tentado influenciar a escolha do sucessor de Bresslau, as instâncias oficiais do Estado alemão - os ministérios da Ciência e das Relações Exteriores - assumiram a frente no processo decisório. ${ }^{54}$ Um mês depois, a Organização Estrangeira foi informada de todo o histórico das negociações até a nomeação de Marcus, que contrariou as expectativas do Partido de ter na cadeira um "professor ariano" à altura da importância de São Paulo para a política cultural alemã. A cidade sediava o Partido no Brasil e possuía o maior número de integrantes no País: 785 membros. ${ }^{55}$

Ernst Marcus chegou a São Paulo em abril de 1936 junto com a esposa, a também pesquisadora Eveline Du Bois Reymond, os quais realizaram prolífica carreira científica na USP, formando gerações de pesquisadores. ${ }^{56}$ 
A diplomacia e outros órgãos alemães tiveram nova oportunidade de apontar um professor para atuar no ensino superior paulista quando a direção da Escola Paulista de Medicina, quase contemporânea da USP, manifestou interesse em nomear um alemão para a cátedra de anatomia patológica. Novamente, tensões e impasses surgiram no processo de negociação, que redundou na contratação de Walter Büngeler.

\section{Um "professor ariano" para o ensino paulista: a cátedra de anatomia patológica da Escola Paulista de Medicina}

Quase ao mesmo tempo em que intelectuais e políticos articulavam a criação da Universidade de São Paulo, outro grupo, formado basicamente por médicos locais, negociava a fundação de uma nova escola de medicina na capital paulista. Liderado pelo renomado clínico Octavio de Carvalho, este grupo estava descontente com o sistema de organização e funcionamento da Faculdade de Medicina de São Paulo, criada em 1912 e incorporada à Universidade de São Paulo quando esta surgiu. ${ }^{57}$ As cátedras, transmitidas de forma quase dinástica dos professores a seus filhos ou apaniguados, deixava poucas oportunidades aos que pretendiam ingressar no corpo docente da Faculdade. A proibição da livre-docência pela reforma feita em 1932 dificultou ainda mais a admissão de professores. De acordo com Márcia Regina Barros da Silva (2001), as mudanças estabelecidas pela reforma, além de modificar a estrutura didática e administrativa da Faculdade de Medicina, restringiram ainda mais o acesso dos estudantes aos cursos. No vestibular de 1933, os aprovados seriam admitidos apenas no curso preparatório denominado pré-médico, de duração de um ano, já que o curso regular seria preenchido pelos que haviam frequentado o preparatório no ano anterior. Esta medida originou um excedente de quase 120 alunos, que haviam obtido a nota mínima, mas não conseguiram se matricular. Esses estudantes começaram a se reunir, reivindicando o aumento do número de vagas no curso pré-médico, demanda amplificada pela imprensa paulista. Octavio de Carvalho e outros médicos interessados no tema do ensino da medicina começaram a participar de tais reuniões, em meio às quais surgiu o projeto de criação da chamada Escola Paulista de Medicina, assim denominada em projeto apresentado em 01 de junho de 1933. A ideia de uma escola médica privada contou com o apoio de representantes das oligarquias e da intelectualidade local. As relações de Octavio de Carvalho - filho do senador Theodoro Dias de Camargo Júnior - contribuíram para a concretização da escola, que inicialmente foi custeada por colaborações dos fundadores. A intenção era que fosse mantida com a mensalidade paga pelos alunos. Inicialmente, a escola foi acomodada numa casa alugada. Em 1936, mudou-se 
para novas instalações, na Vila Clementino, onde também foi construído um hospital para treinamento dos estudantes. ${ }^{58}$

Para a cátedra de anatomia patológica foi nomeado Henrique da Rocha Lima, como vimos, diretor do Instituto Biológico de São Paulo. Ele era do círculo de Octavio de Carvalho, que havia completado sua formação em universidades e institutos alemães. Ele estudara no Hospital Charité quando o amigo de Rocha Lima, Fritz Munk, lá atuava no instituto ligado à segunda cadeira de clínica médica, chefiada pelo internacionalmente famoso Friedrich Kraus. O diretor do Biológico não assumiu a cátedra da Escola Paulista, alegando não poder exercer efetivamente o cargo de docente em paralelo com as muitas atribuições que tinha como administrador de uma instituição científica. ${ }^{59}$ Em seu lugar indicou o anátomo-patologista da divisão animal do Biológico, Juvenal Ricardo Meyer, que em 1936 foi substituído pelo alemão Walter Büngeler, diretor do Instituto de Anatomia Patológica da Academia Médica de Danzig.

As negociações para a contratação de Büngeler foram assumidas por Octavio de Carvalho, que o havia conhecido no período em que atuara no Instituto de Patologia da Universidade de Frankfurt. Carvalho encaminhou o convite a Büngeler em carta de 19 de dezembro de 1935, na qual descreveu a escola médica, os hospitais e as funções que caberiam ao patologista. Perguntou se não seria mais vantajoso se Büngeler viesse como encarregado oficial do governo alemão. Ofereceu nesse sentido os canais privilegiados pelos quais poderia conseguir isso: o ministro das relações exteriores e o embaixador brasileiro em Berlim, Muniz Aragão, dos quais era amigo pessoal. Além disso, havia o amigo em comum, Prof. Volhard, "que é um amigo do Führer" e que poderia orientálo sobre as exigências que deveria requerer nas negociações da vinda ao Brasil. O salário seria pago em moeda brasileira. Citou o exemplo do professor Martin Ficker, bacteriologista e higienista ligado ao Kaiser-Wilhelm Institut, que há anos atuava em São Paulo na direção de uma estação de microbiologia. ${ }^{60}$ Ficker poderia informar-lhe sobre as condições de vida e trabalho no Brasil. Apesar de se tratar de um anátomo-patologista, Rocha Lima não entraria em questão como catedrático da escola paulista - acrescentou Carvalho - porque já estava por demais sobrecarregado com o trabalho no Instituto Biológico. As aulas estavam previstas para começar em março de 1936, ou seja, o processo deveria transcorrer de forma rápida. ${ }^{61}$

Num esforço de conquistar o apoio do consulado alemão de São Paulo, Martin Ficker, que desde 1926 atuava na capital paulista como diretor da estação de microbiologia da Sociedade Kaiser-Wilhelm, aduziu as razões pelas quais considerava importante a contratação de Büngeler. Novamente, a rivalidade com a França e Itália foi utilizada como argumento de persuasão: os alemães deveriam evitar a todo custo que a cátedra da Escola Paulista de Medicina caísse nas mãos dos "rivais". Muito embora nenhuma nação se equiparasse à Alemanha no campo da anatomia 
patológica “desde os tempos de Virchow", jactou-se Ficker, não havia patologista alemão atuante no Brasil, nem mesmo nos hospitais alemães do Rio de Janeiro, São Paulo e Joinville. ${ }^{62}$ Um dos poucos capazes de diagnosticar tumores malignos, efetuar secções histopatológicas e procedimentos de embalsamento - prosseguiu o bacteriologista alemão - era um patologista austríaco "não-ariano". Referia-se a Walter Haberfeld, desde 1916 professor da Faculdade de Medicina de São Paulo. Ficker queixou-se de que nos últimos tempos os professores alemães nomeados para o ensino superior em São Paulo limitavam-se a "não-arianos". Esta seria uma vantagem de Büngeler: ser um ariano, "conforme me garantiu o Dr. Octavio", escreveu. "De não-arianos nós já estamos suficientemente abastecidos", desabafou Ficker. O patologista seria um contrapeso aos demais professores "alemães", grafado entre aspas como sugestão de que ele não considerava os indivíduos de origem judaica autênticos representantes de sua nação. Por fim, Ficker argumentou que a contratação de Büngeler seria um meio de atrair gerações inteiras de médicos formados na Escola Paulista de Medicina à ciência alemã, "ainda mais porque o Dr. Octavio é um grande amigo da Alemanha", emendou. ${ }^{63}$

Em reunião com Hans Speiser - o cônsul alemão na capital paulista, Octavio Carvalho e Martin Ficker tentaram fazer com que a Alemanha assumisse dois terços do salário de Büngeler, ao mesmo tempo em que manteria os vencimentos que ele recebia em seu país, enquanto lecionasse em São Paulo. Eles utilizariam os canais de influência de que dispunham para conseguir isso: o cônsul atuaria junto à Divisão Cultural da chancelaria em Berlim, o legado brasileiro na capital do Reich faria o mesmo, ao passo que Volhard apontaria a importância da contratação do patologista para a promoção da ciência alemã no exterior. ${ }^{64}$

A intenção inicial era que Büngeler iniciasse suas atividades na Escola Paulista de Medicina em março de 1936. Mas as negociações para sua contratação arrastaram-se por quase um ano. Sem conhecer as condições de vida e trabalho na capital paulista, ele pediu aconselhamento aos diplomatas. Entre as motivações que o atraíam ao cargo em São Paulo, ele aduziu: o interesse em observar "doenças exóticas", a possibilidade de atuar como representante da anatomia patológica, “disciplina altamente desenvolvida na Alemanha", e de organizar as atividades de ensino numa escola médica recém-criada. ${ }^{65}$

Büngeler dispunha de uma posição privilegiada em Danzig e por isso exigiu uma série de contrapartidas e garantias por parte de Carvalho. ${ }^{66}$ Este mobilizou todos os meios possíveis para atender às exigências do patologista e viabilizar sua vinda. A fim de conseguir alcançar o valor do salário exigido por Büngeler, Carvalho fez um arranjo com institutos privados, já que a chancelaria alemã não aceitou arcar com a complementação dos vencimentos: a Escola Paulista de Medicina pagaria 3 contos de réis; o Hospital Jaçanã, no qual o patologista trabalharia duas vezes por semana, 
mais 1 conto de réis, e o restante seria completado por laudos anatomopatológicos e pelo Departamento de Assistência aos Psicopatas, totalizando-se 5 contos de réis. ${ }^{67}$

Para complicar o quadro, o Ministério da Ciência da Alemanha pressionou o Ministério das Relações Exteriores nos bastidores para que as negociações de Büngeler com os brasileiros não fossem bem-sucedidas. Como a Academia Médica de Danzig, instituída havia apenas dois anos, encontrava-se numa situação bastante delicada, existia o temor de que a perda de um de seus quadros contribuísse para sua completa desestabilização. ${ }^{68}$ É importante ressaltar a complexidade das circunstâncias políticas que naquele momento envolviam a "cidade livre" de Danzig para compreendermos a postura do Ministério da Ciência do Reich. Desde o Tratado de Versalhes, a cidade estava sob jurisdição da Liga das Nações. Era quase um Estado independente, com constituição e governo próprios. Devido à maioria alemã, a cidade portuária não foi integrada ao estado da Polônia. Com a ascensão dos nazistas ao poder na Alemanha, em 1933, a célula local do Partido conseguiu obter o domínio do governo da cidade, que ainda se encontrava sob os auspícios de um comissário da Liga das Nações. Mas as lideranças nazistas e parte significativa da população alemã local passou a defender a reintegração de Danzig ao território do Reich. Em 1939, o status da cidade seria uma das questões apresentadas por Hitler como argumento para invadir a Polônia. A manutenção de estruturas oficiais, como a Academia de Medicina, com lideranças de origem alemã era uma maneira de manter os vínculos entre a "cidade livre" e o Terceiro Reich. O consulado alemão em Danzig informou que o órgão para assuntos de saúde e política populacional tampouco concordava com o afastamento de Büngeler rumo a São Paulo, pois ele havia se mostrado apto em lidar com as delicadas questões que envolviam a política alemã para o leste europeu e gozava de grande confiança do diretor local (Gauleiter) do Partido Nazista. ${ }^{69}$ A Divisão Cultural em Berlim afirmou preferir a ida de Büngeler para São Paulo à sua permanência em Danzig. ${ }^{70}$

Uma das principais exigências de Büngeler era que o contrato fosse de 15 anos e que ele mantivesse seu cargo na Alemanha, afastando-se na condição de licenciado. Apesar das garantias de Octavio de Carvalho, que o patologista apresentou ao Ministério da Ciência, ele se sentiu inseguro em fechar o contrato com a Escola Paulista de Medicina. Segundo Büngeler, tais garantias oferecidas em carta não tinham caráter legal, uma vez que não haviam sido formalizadas num contrato. Se inicialmente a oferta era de um salário de 3 Mil-Réis/mensal pela cátedra de anatomia patológica mais 2 mil de adicional pelo trabalho no Hospital do Jaçanã, posteriormente Carvalho falou em 24 Mil-Réis por ano, mais 12 Mil-Réis de adicional. A Escola Paulista oferecera ainda custear a viagem, mas o montante, segundo Büngeler, não cobria os gastos da passagem dele e da mulher. A forma como as negociações vinham sendo conduzidas, queixou-se o patologista ao Ministério da Ciência, estava atiçando sua desconfiança, intensificada pela informação de que o 
embaixador brasileiro em Berlim era cunhado de Carvalho. Dessa forma, pediu que o Ministério das Relações Exteriores intermediasse a formulação de um contrato com a escola médica brasileira. " ${ }^{71}$ "É impossível, sem esse tipo de garantia legal, deixar o posto que atualmente ocupo", escreveu Büngeler ao consulado alemão de Danzig. ${ }^{72}$

Acionado por Octavio de Carvalho, Rocha Lima esclareceu a Büngeler que a lei brasileira não autorizava contratos de 15 anos com estrangeiros, no máximo de quatro anos, renováveis por mais quatro. Também informou ao colega alemão que médicos estrangeiros só podiam exercer a medicina no Brasil se fizessem uma espécie de prova, além de não poderem emitir laudos técnicos. O diretor do Biológico enfatizou que transmitia tais informações em caráter não-oficial, fazendo-o pessoalmente e na qualidade de "intermediário e tradutor" 73 , função que tantas vezes desempenhara no esforço de estreitar os laços da ciência brasileira com a alemã (SILVA, 2011). Também a pedido de Carvalho, Martin Ficker escreveu a Büngeler carta na qual descreveu de forma minuciosa os gastos para viver em São Paulo, procurando comprovar que o salário que lhe fora oferecido era mais que suficiente para desfrutar de conforto na cidade brasileira. ${ }^{74}$

Novamente o cônsul de São Paulo entrou em cena para viabilizar a contratação de um professor alemão para o ensino superior local. O cônsul conversou pessoalmente com Octavio de Carvalho, que lhe mostrou as futuras instalações da escola médica e do hospital e garantiu que estava disposto a pagar um salário de 6 Mil-Réis a Büngeler, além de firmar um contrato de 3 a 5 anos, o máximo permitido pela lei brasileira. ${ }^{75} \mathrm{O}$ embaixador brasileiro em Berlim, Muniz de Aragão, estava habilitado a fechar o contrato com o patologista e a discutir com ele todos os pontos relativos ao documento. "Sem dúvida nenhuma o Dr. Carvalho dá grande valor à vinda do Dr. Büngeler, em quem aparentemente tem grande confiança", acrescentou o cônsul. Prova disso teve o próprio Büngeler, quando Carvalho lhe escreveu comunicando a disponibilidade para pagar 6 Mil Réis, dos quais metade seria fornecida pela Escola de Medicina, e a outra metade, por convênio com outras instituições (Instituto de Leprologia Conde de Lara, Departamento de Assistência aos Psicopatas, Instituto Bernardes de Oliveira, Casa de Saúde Santa Inês, Hospital Jaçanã e Hospital Juquery). Dessa forma, Büngeler ganharia o dobro do que a USP pagava aos professores estrangeiros. O contrato seria válido por quatro anos, prorrogável por mais quatro, de acordo com as regras brasileiras. "A melhor garantia de um contrato é a compreensão e conhecimento da honra do outro e o fundamento da amizade, resultante de uma longa convivência sob o signo da confiança mútua”, asseverou Carvalho. Além do apelo pessoal, o médico paulista afiançou que o objetivo era “fundar uma nova escola de anatomia patológica segundo os princípios mais modernos". Tal projeto não poderia ser construído e consolidado em menos de 15 anos, afirmou. ${ }^{76}$ 
Um último aspecto das negociações ainda estava pendente. Além das garantias por parte da Escola Paulista de Medicina, Büngeler queria assegurar seu posto na Alemanha para o caso de um eventual retorno. ${ }^{77}$ Carvalho novamente acionou seus canais para conseguir que o patologista obtivesse do governo do Reich uma licença de três a quatro anos, sem prejuízo de seus direitos. Para isso, mobilizou José Carlos de Macedo Soares, ministro das relações exteriores de Vargas, pedindo que ele interviesse junto à Alemanha, e o professor Volhard, amigo pessoal de Hitler. Ele não dispensou o argumento das facilidades que haviam sido concedidas por França e Itália aos professores nomeados para São Paulo. A atuação de Büngeler na cátedra de anatomia patológica, argumentou Carvalho a Volhard, seria uma excelente estratégia de propaganda cultural, mas dependia apenas "da colaboração do governo alemão". ${ }^{78}$

Finalmente, em 29 de junho de 1936, o consulado de Danzig comunicou que Büngeler fechara o contrato com o governo de São Paulo. Havia obtido a licença de quatro anos e uma ajuda de 3.500 marcos do Ministério das Relações Exteriores para a mudança, além da passagem de primeira classe oferecida por Octavio de Carvalho. Em julho daquele ano ele chegou a São Paulo. Na Escola Paulista de Medicina, Büngeler organizou o Instituto de Anatomia Patológica nos moldes dos institutos alemães. Interessou-se bastante pelos estudos anatomopatológicos da lepra, sobre os quais publicou em periódicos locais e conferenciou nas associações médicas. Em março de 1937, Büngeler admitiu em carta que estava bastante satisfeito na Escola Paulista. O médico paulista Jorge Michalany, falecido em julho de 2012, foi aluno de Büngeler, a quem se referiu como "digno representante da escola alemã (na qual o patologista forma-se na sala de autópsia)”. De acordo com Michalany (2006), "Büngeler tinha formação hospitalar, grande habilidade na execução das autópsias e familiaridade com a patologia experimental”.

Walter Büngeler foi um destacado defensor da política cultural externa alemã executada por meio da medicina. Ele foi nomeado senador da Academia Médica Germano-Ibero-Americana, criada em 1935 para promover o intercâmbio acadêmico da Alemanha com médicos latinoamericanos e se esforçou em promover a visita de médicos alemães a São Paulo. Ferrenho antissemita e alinhado com a ideologia nazista, Büngeler procurou não se integrar com os alemães de origem judaica que atuavam no ensino superior paulista, como os professores da USP. Em relatório ao Ministério das Relações Exteriores, saudou o fato de Octavio de Carvalho - segundo ele, "convicto antissemita e grande admirador da nova Alemanha" - ter mantido a Escola Paulista de Medicina totalmente livre de emigrantes judeus. Em relação ao Instituto Biológico, queixou-se de que ele se encontrava completamente "judaizado" (verjudet). O próprio diretor, Rocha Lima, "certamente de origem luso-judaica" - especulou Büngeler, convidara-o para um jantar em sua casa, ocasião em que encontrou apenas emigrantes judeus. "Para mim foi uma situação muito 
embaraçosa”, escreveu a Berlim o patologista, que transplantava para solo brasileiro os conflitos do ambiente político e social do Terceiro Reich. ${ }^{79}$ A entrada do Brasil na Guerra contra os países do Eixo, em 1942, obrigou Büngeler a retornar à Alemanha, enquanto que os professores alemães da USP puderam permanecer em São Paulo. Naturalizaram-se brasileiros e viveram na capital paulista até a morte, com exceção de Rawitscher, que retornou a Freiburg depois de sofrer um ataque cardíaco. O patrimônio científico desses professores manteve-se vivo por intermédio dos discípulos, que deram sequência às tradições de pesquisa estabelecidas por eles.

\section{Conclusões}

Acompanhando o processo que levou à nomeação de professores alemães para o ensino superior de São Paulo, pode-se notar o papel ativo que os acadêmicos tiveram nas negociações que os trouxeram à capital paulista. De forma semelhante ao que fizeram os franceses contratados pela USP, os alemães procuraram obter vantagens do governo do Reich, explorando as rivalidades e disputas diplomáticas com a França e - em menor medida - a Itália, e se colocando como portavozes da ciência alemã e pontos de apoio da política cultural endereçada ao Brasil. Assim como os franceses, alemães como Ernst Bresslau manifestaram consciência do seu papel como promotores da cultura de seu país e do leque de vantagens aberto pelos esforços de diplomacia cultural. Enquanto a França instituiu, já em fins do século XIX, os nichos institucionais voltados à difusão da cultura francesa no exterior, na Alemanha só se ganharia lugar de destaque na política cultural externa depois da Primeira Guerra. ${ }^{80}$

Foi somente com a criação da Divisão Cultural no Ministério das Relações Exteriores, em 1920, que a diplomacia alemã passou a coordenar de forma sistemática o intercâmbio científico com outros países, estabelecido por meio de viagens de acadêmicos ao exterior, publicações, congressos, recrutamento de estudantes e recepção de professores estrangeiros. A iniciativa reflete a clara tentativa de instrumentalização, por parte da diplomacia alemã, das relações estabelecidas pelos acadêmicos com o exterior. Para estes, o Ministério das Relações Exteriores figurou como um patrono da atividade científica, uma vez que se dispôs a financiar viagens e projetos de trocas intelectuais. A maior parte desses professores também se engajou na diplomacia cultural impulsionada pelo espírito nacionalista que tingiu as relações científicas transnacionais na primeira metade do século XX, sobretudo nos anos 1920 e 1930. Entretanto, o antissemitismo tornado política oficial pelo Terceiro Reich desde a conquista do poder pelos nazistas, em 1933, restringiu de forma significativa o espaço de manobra dos acadêmicos de origem judaica, como eram os nomeados para a USP. Por mais que eles se colocassem a serviço da política cultural externa, o 
Estado alemão, de um modo geral, tendeu a não os identificar como autênticos representantes de uma nação ancorada na ideia da pureza racial. Vozes dissonantes, como a do cônsul alemão de São Paulo, tentaram neutralizar esse "problema", apresentando razões de ordem prática associadas à política cultural externa. Afinal de contas, a ocupação de uma cadeira numa universidade paulista oferecia amplas possibilidades em termos de diplomacia cultural. O prestígio associado à ocupação de uma cátedra, o contato cotidiano com os alunos, professores e membros das elites sociais e políticas e a promoção das tradições científicas e culturais às quais o catedrático estava ligado eram fatores que tornavam os acadêmicos eficientes executores da política cultural. Por este motivo, as cátedras haviam sido tão cobiçadas pelos franceses e italianos.

Cumpre observar que foram os órgãos envolvidos com a política externa, ciência e educação, com clara preponderância do Ministério das Relações Exteriores, os que assumiram a frente nas negociações para a vinda dos professores alemães. A Organização do Partido Nazista para o exterior procurou influenciar o processo decisório e estar a par das negociações, mas não teve um papel de relevo nelas. Não seriam raros os conflitos entre os órgãos do Estado e do Partido, pois a sobreposição de atribuições foi um traço bastante presente na burocracia nazista. Nos primeiros anos, o Ministério das Relações Exteriores se esforçou por manter sua autonomia na política externa. Grande parte dos quadros permaneceu em seus postos, e houve traços de continuidade com a política externa da República de Weimar, como os esforços por revisão do Tratado de Versalhes. De acordo com Michalka (2002, p. 284), além deste, outros dois eixos pautariam a diplomacia do Terceiro Reich nos primeiros anos: o rearmamento da Alemanha, orientado pela política armamentista das potências vitoriosas na Primeira Guerra, e a revisão das fronteiras territoriais, sobretudo a leste, onde os alemães haviam sofrido as maiores perdas de território. Em termos de diplomacia cultural, os nazistas tendiam a concebê-la sob o prisma da ideologia e como arma de propaganda política, percepção diferente daquela cultivada na chancelaria (ZARIFI, 2007, p. 203-4). Com a Segunda Guerra, a abordagem "propagandista" acabaria prevalecendo.

São notórias as discrepâncias entre as negociações travadas por Ernst Bresslau e aquelas que envolveram a vinda de Walter Büngeler. Pelo fato de não se tratar de um indivíduo de origem judaica, Büngeler pôde impor condições, negociar regalias e, por fim, emigrar para o Brasil em situação bastante vantajosa. Esta "vantagem", por sua vez, obrigou-o a retornar à Alemanha em 1942, ao passo que os alemães de origem judaica puderam aqui permanecer, estabelecendo sólidas trajetórias profissionais, formando "escola" e contribuindo de forma decisiva para a abertura de novas frentes de pesquisa e consolidação de campos de saber, como a química e a biologia. Não cabe no espaço desse trabalho discorrer de forma aprofundada sobre as consequências da vinda 
desses professores alemães, em termos de atividades de pesquisa e ensino. Em linhas gerais, vale mencionar a convergência das tradições de conhecimento que eles trouxeram em sua "bagagem", com problemáticas de pesquisa associadas às circunstâncias locais. Ilustração exemplar disso é o caso de Félix Rawitscher, um estudioso das relações das plantas com o ambiente circundante, que aplicou seus conhecimentos à análise da vegetação do cerrado, abrindo caminho para a exploração científica deste importante bioma brasileiro. Tal caminho seria percorrido por seu discípulo, o botânico Mário Guimarães Ferri. Walter Büngeler empregou sua expertise em anatomia patológica ao estudo da lepra, questão relevante da saúde pública naqueles anos. Nesse sentido, não foi uma mera "contribuição" alemã à ciência brasileira, como se estivéssemos lidando com tradições estanques ou influências unidirecionais, mas a convergência de tradições, resultante de interações socioculturais, circulação de saberes e negociações. Os professores alemães, tanto na USP quanto na Escola Paulista de Medicina, desempenharam papel importante na consolidação e amplificação de um espaço, inicialmente limitado, voltado ao cultivo da atividade científica. Foram seus alunos e discípulos os responsáveis por expandir as fronteiras das práticas de pesquisa encetadas nos institutos. Ao trazerem consigo o ethos de ensino e pesquisa responsável, diante do prestígio acadêmico da Alemanha, os alemães contribuíram para a fusão de "modelos acadêmicos, tradições e experiências" que, segundo Simon Schwartzman, "acabou por ser um dos pontos fortes da Universidade de São Paulo" (SCHWARTZMAN, 2001). O mesmo pode ser dito em relação à Escola Paulista de Medicina, que, no entanto, se constituiu com menor presença de docentes estrangeiros, em comparação com a USP.

Por fim, cabe mencionar que o caso da contratação de professores para a USP e Escola Paulista de Medicina evidencia o papel dos agentes locais - no caso, dos brasileiros - nas políticas de diplomacia cultural formuladas a partir dos países europeus. As rivalidades e disputas diplomáticas nos anos que antecederam a Segunda Guerra Mundial abriram oportunidades aos que se dedicavam à implantação de centros de ensino e pesquisa no Brasil. Vantagens e benefícios na contratação de professores estrangeiros foi uma dessas oportunidades, que ainda contribuíram para a legitimação e decolagem dos projetos institucionais formulados por seus idealizadores.

\section{Referências Bibliográficas}

ANTUNHA, H. C. Universidade de São Paulo - fundação e reforma. São Paulo: FEUSP, 1974.

AUST, C. B. Der Beitrag deutscher Wissenschaftler zum Aufbau der Philosophischen Fakultät der Universität São Paulo. Staden-Jahrbuch, São Paulo: Instituto Martius-Staden, 1964, p. 197-211. 
AZEVEDO, F. As ciências no Brasil. 2 v. São Paulo: Melhoramentos, 1955.

BENZ, W. Bilder vom Juden. Studien zum alltäglichen Antisemitismus, C.H. Beck, München 2001.

BENZ, W. Deutsche Juden im 20. Jahrhundert: eine Geschichte in Porträts. München: Beck, 2011.

BRESSLAU, E. Arquivos do Instituto Biológico de São Paulo, vol. 3, p. 69-73, 1930.

CARDosO, I. A. R. A Universidade da Comunhão Paulista. São Paulo: Cortez, 1982.

CAMPOS, E. S. História da Universidade de São Paulo. São Paulo: Edusp, 1954.

DEICHMANN, U. Biologists under Hitler. Cambridge/ Massachussets/ London: Harvard University Press, 1999.

DIETRICH, A. M. Caça às Suásticas: o Partido Nazista em São Paulo sob a mira da Polícia Política. São Paulo: Humanitas/ Imprensa Oficial/ FAPESP, 2007.

DIETRICH, A. M. Nazismo tropical? O Partido Nazista no Brasil. 2007. Tese (Doutorado em História Social) - Universidade de São Paulo, São Paulo, 2007b.

DIETRICH, M. R. Richard Goldschmidt: Hopeful Monsters and Other "Heresies". Nature Reviews Genetics, vol. 4, 2003, p. 68-74.

DUARTE, P. Memórias, Volume 3 - “Selva Oscura”. São Paulo: Hucitec, 1976.

DÜWELL, K. Deutschlands auswärtige Kulturpolitik, 1918-1932 - Grundlinien und Dokumente. Köln: Bohlau Verlag, 1976.

FERRI, M. G. A Botânica no Brasil. In AZEVEDO, Fernando de (ed). As ciências no Brasil, v. 2 , São Paulo:, 1955, p. 149-200.

FRIEDLÄNDER, S. A Alemanha nazista e os judeus - Os anos da perseguição, 1933-1945. Tradução Fany Kon et. al. São Paulo: Perspectiva, 2012.

JUSATZ, H. Neue Deutsche Biographie, Bd. 5. Berlin: Duncler \& Humdlot, 1961, p. 134-5.

LESSA, M. L. A Aliança Francesa no Brasil: política oficial de influência cultural. Varia História, Belo Horizonte: UFMG, n. 13, 1994, p. 78-95.

LIMONGI, F. M. P. Educadores e empresários culturais na construção da USP. 1988. Dissertação (Mestrado) - Instituto de Filosofia e Ciências Humanas, Unicamp, 1988.

MAgalhães, M. B. de. Pangermanismo e nazismo: a trajetória alemã rumo ao Brasil. Campinas: Editora da UNICAMP/FAPESP, 1998

MARINHO, M. G. S. M. C. O papel da Fundação Rockefeller na organização do ensino e da pesquisa na Faculdade de Medicina de São Paulo (1916-1931). 1993. Dissertação (Mestrado) - 
Departamento de Política Científica e Tecnológica/ Instituto de Geociências, Unicamp, Campinas, 1993.

MARINHO, M. G. S. M. C.; MOTA, André (Orgs). Da Faculdade de Medicina e Cirurgia de São Paulo à Faculdade de Medicina da Universidade de São Paulo: conjunturas e contextos. São Paulo CDG, 2012, 2 vols

MENDES, E. G. Ernst Marcus. Revista do Instituto de Estudos Avançados, São Paulo: USP, vol. 8, n. 22, 1994, p. 209-213.

MESQUITA FILHO, J. Política e Cultura. São Paulo: Martins, 1969.

MORAES, L. E. Ein Volk, ein Reich, ein Führer! A Seção Brasileira do Partido Nazista e a Questão Nacional. 1996. Dissertação (Mestrado em Antropologia Social) - Museu Nacional, Universidade Federal do Rio de Janeiro, 1996.

MICHALANY, J. Walter Büngeler, inovador da anatomia patológica no Brasil. XI Congresso da Sociedade Brasileiro de História da Medicina.

MICHALKA, W. Hitlers Aussenpolitik und der Weg zum deutschen Weltmachtanspruch. In SÖSEMANN, Bernd. Der Nationalsozialismus und die deutsche Gesellschaft: Einführung und Überblick. Stuttgart/ München: Deutsche Verlags-Anstalt, 2002, p. 292-297.

MORRETES, B. L. Felix Rawitscher. Estudos Avançados. São Paulo: Universidade de São Paulo, vol. 8, n. 22, 1994, p. 205-208.

MOTOYAMA, S. (Org.). Prelúdio para uma História: ciência e tecnologia no Brasil. São Paulo: Edusp, 2003

NADAI, E. Ideologia do progresso e ensino superior, São Paulo (1891-1934). São Paulo: Loyola, 1987.

NEUBERGER, H. Freimaurerei und Nationalsozialismus. Die Verfolgung der deutschen Freimaurerei durch völkische Bewegung und Nationalsozialismus 1918-1945. Hamburg: Bauhütten Verlag, 1980.

NOMURA, H. Vultos da Zoologia Brasileira, Coleção Mossoroense, série C, Mossoró/ Natal: Fundação Vingt-un Rosado e Secretaria de Educação, Cultura e Desporto do Rio Grande do Norte, vol. 771, 1992.

O ESTAdo DE SÃo PAULO, Universidade de São Paulo - A missão do dr. Theodoro Ramos e os professores contratados, 30.05.1934

O ESTADO DE SÃO PAULO, Professor Felix Rawitscher, 05.01.1958

PETITJEAN, P. As missões universitárias francesas na criação da Universidade de São Paulo (1934-1940). In: HAMBURGER, Amélia Império et. al. (Orgs). A Ciência nas Relações BrasilFrança (1850-1950). São Paulo: Edusp/ Fapesp, 1996, p. 259-330.

PETITJEAN, P. Entre ciência e diplomacia :a organização da influência científica francesa na América Latina. In: HAMBURGER, Amélia Império et. al. (Orgs). A Ciência nas Relações Brasil-França (1850-1950). São Paulo: Edusp/ Fapesp, 1996b, p. 89-120. 
RAWITSCHER, F. Der Geotropismus der Pflanzen. Jena: Gustav Fischer, 1932.

RIBEIRO, M. A. R. História, Ciência e Tecnologia: 70 anos do Instituto Biológico de São Paulo na defesa da agricultura, 1927-1997. São Paulo: Instituto Biológico, 1997.

SÁ, M. R.; VIANNA, L. M. La science médicale entre la France et le Brésil: stratégies d' échange scientifique dans la période de 1 entre-deux guerres". Paris, Cahiers des Amériques Latines, v. 65,2010 , p. $65-88$.

SANTOS, M. C. L. (Org). Universidade de São Paulo: alma mater paulista - 63 anos. São Paulo: EdUSP/ Imprensa Oficial, 1998.

SAWAYA, P. Professor Dr. Bresslau: traços biográficos. Anuário da Faculdade de Filosofia, Ciências e Letras da USP, 1935.

SAWAYA, Paulo. Professor Ernst Bresslau in Memoriam. Revista de Biologia, São Paulo, vol. 6, n. 1, 1935b.

SCHPUN, M. Justa. Aracy de Carvalho e o resgate de judeus: trocando a Alemanha nazista pelo Brasil. Rio de Janeiro: Civilização Brasileira, 2011.

SCHWARTZMAN, S. Um espaço para a ciência: a formação da comunidade científica no Brasil. Brasília: Ministério da Ciência e Tecnologia, 2001.

SENISE, P . Origem do Instituto de Química da USP - reminiscências e comentários. São Paulo: Instituto de Química da USP, 2006.

SILVA, A. F. C. Ciência nos cafezais: a campanha contra a broca-do-café em São Paulo (19241929). 2006. Dissertação (Mestrado em História das Ciências e da Saúde) - Casa de Oswaldo Cruz/ Fundação Oswaldo Cruz, 2006.

SILVA, A. F. C. da. A trajetória científica de Henrique da Rocha Lima e as relações BrasilAlemanha (1901-1956). 2011. Tese (Doutorado em História das Ciências e da Saúde) - Casa de Oswaldo Cruz/ Fundação Oswaldo Cruz, 2011.

SILVA, M. R. B. da. O ensino médico em São Paulo e a criação da Escola Paulista de Medicina. In: História, Ciências, Saúde - Manguinhos, Rio de Janeiro, v. VIII, n. 3, 2001, p. 543-68.

SILVA, M. R. B. da. Estratégias da ciência: a história da Escola Paulista de Medicina (19331956). Bragança Paulista: Editora Universitária São Francisco, 2003

SUPPO, H. A política cultural da França no Brasil entre 1920 e 1940: o direito e o avesso das missões universitárias. Revista de História, São Paulo, 2000, p. 309-345.

WEHEFRITZ, V. Ein Herz leidet an Deutschland: Professor Dr. Ernst Bresslau (1877-1935) - ein deutsches Gelehrtenschicksal im 20. Jahrhundert. Universität im Exil - Biographisches Archiv des verfolgten Universitätsprofessoren 1933-1945, Nr. 1, Dortmund: Universitätsbibliothek Dortmund, 1995.

ZARIFI, M. Using natural sciences for cultural expansion: the national socialist agenda for the Balkans. In: The Historical Review/ La Revue Historique, v. IV, p. 199-233, 2007. 


\section{Notas}

${ }^{1}$ Entre a abundante literatura que trata da fundação e trajetória posterior da USP, cumpre destacar as obras de CAMPOS, 1954; ANTUNHA, 1974; CARDOSO, 1982; LIMONGI, 1988; SANTOS, 1998; SCHWARTZMAN, 2001; MOTOYAMA, 2003.

${ }^{2}$ Em entrevista a Simon Schwartzman, Paulo Duarte afirma que, na opinião dele e de Júlio de Mesquita Filho, apenas três pesquisadores brasileiros estariam aptos a fazer parte da nova universidade: Henrique da Rocha Lima, "um marco mundial [...], que era nosso companheiro", mas que estava envolvido com a direção do Instituto Biológico de São Paulo; Theodoro Ramos, matemático e professor da Escola Politécnica, e André Dreyfus, biólogo, professor da Faculdade de Medicina (DUARTE, 1976).

${ }^{3}$ Visão geral das contribuições de Marcus para a zoologia no Brasil encontra-se em MENDES, 1994.

${ }^{4}$ Os trabalhos de cunho histórico que abordam a criação da USP divergem quanto às relações da fundação da universidade com o projeto político e cultural das oligarquias paulistas. Schwartzman (2001) vê a criação da USP como ligada ao esforço das elites paulistas para recuperar a hegemonia perdida com a revolução de 1930 e com a derrota sofrida nas batalhas de 1932. Antunha (1974), por sua vez, situa esse processo no contexto de lutas entre as forças autoritárias e centralizadoras de Vargas e o espírito liberal e democrático do grupo de Mesquita Filho. Contrapondo-se a Antunha, Cardoso (1982) identifica traços de autoritarismo nos projetos do chamado "grupo do Estado", nos quais a USP teria ocupado posição central. Nesse quadro, a universidade foi produto das lutas por hegemonia política e cultural travadas pelo "grupo do Estado" que, dessa forma, teria atuado como um "partido ideológico". Em oposição a esses autores, Limongi (1988) defende que a USP não foi o resultado lógico e necessário da luta política travada pelas oligarquias políticas em suas ambições por hegemonia, mas produto "da expansão do aparelho de ensino paulista e das lutas pelo seu controle", atendendo aos objetivos de formar "elites desinteressadas" e professores secundários.

${ }^{5}$ Isso a diferenciava das universidades criadas até então, que haviam consistido em mera reunião de escolas de ensino superior, como a Universidade do Rio de Janeiro, de 1920, que reunira a Faculdade de Medicina, a Escola de Direito e a Escola Politécnica do Rio de Janeiro. A ideia de uma Faculdade de Filosofia, Ciências e Educação como núcleo aglutinador da universidade, dedicada à formação de cientistas versados na pesquisa pura e professores para atuar no ensino secundário, já estava presente no decreto instituído pela reforma Francisco Campos, de 1931 SCHARTZMAN, 2001.

${ }^{6}$ Júlio de Mesquita Filho (1969, p. 192), em texto em que recorda o momento de criação da USP: “Ora, éramos irredutivelmente liberais. Tão convictamente liberais que nos julgávamos na obrigação de tudo fazer para que o espírito em que se inspirasse a organização da Universidade se mantivesse exacerbadamente liberal. Era essa, de resto, a resultante do propósito em que sempre estivéramos de tentar o impossível para mantê-la dentro das mais legítimas tradições da nossa grei e de fazer dela um reduto daquilo que fora invariavelmente, e desde os tempos do BrasilColônia, uma constante da nacionalidade. Essa nossa posição obrigava-nos a evitar que as cátedras da Faculdade de Filosofia pudessem cair nas mãos dos adeptos do credo italiano, sobretudo aquelas que mais aptas se mostravam a influir na formação moral da nossa juventude. Concorria para complicar o problema o fato de contar São Paulo com um número elevado de filhos da Península, a maioria dos quais não escondia as suas propensões para aceitar as diretrizes da Roma fascista. Ameaça de monta e tanto mais digna de nossos cuidados quanto cada dia se mostrava mais impertinente a pressão que sobre o governo paulista exerciam a colônia e o governo italianos. Pretendiam impor a vinda de numerosos membros das Universidades fascistas para integrar a nova congregação. Contornamos a dificuldade oferecendo à Itália algumas das cadeiras de ciência pura - Análise Matemática, Geometria, Estatística, Geologia, Mineralogia e Língua e Literatura italianas. Conservávamos para a França, líder da liberal democracia, aquelas de que dependia diretamente a formação espiritual dos futuros alunos: Filosofia, Sociologia, Economia Política, Política, Geografia Humana, Letras Clássicas e Língua e Literatura Francesas. As demais - química e História Natural - seriam preenchidas por alemães expulsos ou em vésperas de o ser de sua pátria pelo hitlerismo. Assim, evitava-se a quebra do sentido liberal da evolução brasileira. As futuras "elites" não seriam vítimas da deformação intelectual resultante da prédica, nas cátedras, de teorias esdrúxulas, que repugnavam à índole e às tendências inatas da nossa gente.

${ }^{7}$ Paulo Sawaya em depoimento a Simon Schwartzmann citado em PETITJEAN, 1996, p. 261.

${ }^{8}$ Sobre a criação do Instituto Biológico de Defesa Agrícola e Animal, depois denominado Instituto Biológico de São Paulo, ver RIBEIRO, 1997 e SILVA, 2006.

${ }^{9}$ Neiva era aliado do tenente João Alberto, que o nomeou secretario do interior de São Paulo em 1930. A aliança com os tenentes garantiu-lhe ainda o posto de interventor em seu estado natal, a Bahia, em 1931, mas conflitos políticos locais obrigaram-no a se afastar. A identificação com João Alberto e os demais grupos envolvidos na revolução de 1930 colocaram-no em posição difícil quando as tropas paulistas se revoltaram contra o governo de Getúlio Vargas. A fuga de Neiva e sua sucessão no Biológico por Rocha Lima é um episódio bastante nebuloso, em que acusações de traição política estiveram presentes (SILVA, 2011, p. 603-15).

${ }^{10}$ A instituição também foi representada no Conselho de criação da USP pelo fitopatologista Agesilau Bitancourt, composto, além de Rocha Lima, por Júlio de Mesquita Filho, Theodoro Ramos, Francisco E. Da Fonseca Telles, Fernando Azevedo, Raul Briquet, Vicente Ráo e Antonio Ferreira de Almeida Junior.

História (São Paulo) v.32, n.1, p. 401-431, jan/jun 2013 ISSN 1980-4369 
${ }^{11}$ Correspondência de Rocha Lima com Júlio de Mesquita Filho. Fundo Rocha Lima, Centro de Memória do Instituto Biológico de São Paulo.

${ }^{12}$ Ernst Ludwig Bresslau nasceu em 10 de outubro de 1877 em Berlim. Iniciou seus estudos em medicina na Universidade de Estrasburgo e os concluiu em 1902, Munique, com tese sobre o desenvolvimento dos órgãos mamários nos marsupiais, doutorando-se em ciências naturais. Entre 1901 e 1907 foi assistente de Alexander Goette no Instituto de Zoologia de Estrasburgo. Sua tese de livre-docência, de 1903, abordou o desenvolvimento dos vermes turbelários. Em 1904, Bresslau visitou o Brasil como médico de um navio, sendo nomeado professor da Universidade de Estrasburgo em 1909. Visitou novamente o País entre junho de 1913 e julho de 1914, em viagem financiada pela Academia de Ciências de Berlim e pela Universidade de Estrasburgo, para coletar material concernente a seus estudos sobre a embriologia dos marsupiais e sobre o desenvolvimento das planárias terrestres. Durante a Primeira Guerra, atuou como médico militar. A ocupação da Alsácia pelos franceses levou Bresslau a deixar Estrasburgo em 1919, e ele veio a tornar-se chefe da seção de zoologia da "Georg-Speyer Haus", instituição estabelecida por Paul Ehrlich, em Frankfurt com patrocínio da viúva do banqueiro Georg Speyer, Franziska Speyer. Em 1925, Bresslau foi convidado para dirigir o Instituto de Zoologia da Universidade de Colônia, cargo que ocupava quando veio outra vez ao Brasil, em 1929, novamente para coletar material zoológico. Em 1933 foi aposentado pelo governo nazista, ocasião em que aceitou o convite para ocupar a cátedra de zoologia da USP. Faleceu em São Paulo em 1935. As contribuições de Bresslau versam, entre outras coisas, sobre o desenvolvimento dos vermes turbelários, sobre a origem da bolsa dos marsupiais e sobre o processo de desenvolvimento que dá origem às glândulas mamárias dos mamíferos. À luz da teoria darwinista, Bresslau pôde contribuir, a partir do estudo dos processos embriológicos, para o esclarecimento da origem dos mamíferos em sua relação com os répteis e aves. Sobre Bresslau ver SAWAYA, 1935, 1935b; AUST, 1964; NOMURA, 1992; WEHEFRITZ, 1995.

${ }^{13}$ Carta de Rocha Lima a Fritz Munk de 09.06.1934. Arquivo Rocha Lima, Centro de Memória do Instituto Biológico de São Paulo.

${ }^{14}$ Carta de Rocha Lima a Fritz Munk de 09.06.1934. Arquivo Rocha Lima, Centro de Memória do Instituto Biológico de São Paulo.

${ }^{15}$ Em suas memórias, Júlio de Mesquita Filho (1969, p. 192) afirma: “As outras cadeiras - química e história natural seriam ocupadas por alemães expulsos do seu país pelo hitlerismo. Desta forma, podíamos proteger o sentido liberal da evolução brasileira". Dá a entender que havia sido uma orientação pré-estabelecida por ele e demais indivíduos envolvidos na criação da USP a contratação de professores alemães de origem judia.

${ }^{16}$ Nascido em Karlsruhe em 1891, Heinrich Rheinboldt estudou química e geologia na Escola Técnica de Karlsruhe. Doutorou-se em química pela Universidade de Estrasburgo em 1918 com tese sobre o fenômeno da adsorção em gel anorgânico. Retornou a Karlsruhe, onde estudou com os químicos Engler e Pfeffer, seguindo este a Bonn, onde foi seu assistente. Em 1924 apresentou tese de livre-docência intitulada "Contribuições à sistemática das ligações químicas". Quatro anos depois tornou-se catedrático e em 1930 encarregou-se do ensino de química analítica e inorgânica. Entre 1925 e 1932 realizou uma série de pesquisas sobre as modalidades de reação do cloreto de nitrosila. Nomeado para a cadeira de química da recém-criada Faculdade de Filosofia da USP, Rheinboldt organizou um núcleo de ensino e pesquisa em química aos moldes dos institutos alemães. Em 1936 recebeu o prêmio Van-T' Hoff por seus estudos sobre ligações sulfúreas. Ele ganhou notabilidade com as pesquisas sobre a composição e degradação da acetil-colina. Dedicou-se também à investigação de ligações químicas envolvendo o selênio e o telúrio, além de ter contribuído bastante para a simplificação do método de análise térmica dos componentes químicos. Os escritos memorialísticos ressaltam a habilidade didática de Rheinboldt, que se esforçou para incluir demonstrações experimentais em suas aulas. Ele morreu em São Paulo em 05 de dezembro de 1955, cinco anos depois de ter recusado o convite, por parte do governo alemão, de retornar ao instituto de química de Bonn. Sobre Rheinboldt, ver AUST, 1964, p. 206-8 e SENISE, 2006.

${ }^{17}$ Heinrich Hauptmann nasceu em Bresslau em 1905. Trabalhou em Göttingen com o Nobel de química Adolf Windaus, premiado em 1928 pela identificação do colesterol. Em 1946 tornou-se professor catedrático da Faculdade de Filosofia. Com o falecimento de Rheinboldt, em 1955, assumiu a direção geral do Instituto de Química da USP, engajando-se no projeto de um conjunto arquitetônico que abrigasse as salas e laboratórios de química. Faleceu em São Paulo, cinco anos depois, com 55 anos de idade. Ver SENISE, 2006.

${ }^{18}$ A documentação do Ministério das Relações Exteriores não tem registros das negociações que envolveram a contratação de Hauptmann. Como ele se encontrava em Genebra, é razoável supor que a diplomacia suíça tenha sido mobilizada na vinda do químico alemão para a USP.

${ }^{19}$ Em contraponto ao texto laudatório de Paschoal Senise, da primeira turma de alunos de Rheinboldt e Hauptmann, cabe mencionar o depoimento do físico Paulus Pompéia, no qual ele afirma que ambos "eram grandes químicos mas do século XIX" (SCHWARTZMAN, 2001, p. 198). De acordo com Mors, que estudou com Hauptmann a química dos produtos naturais, os alemães haviam obtido grandes avanços na química clássica, mas ignoravam os enunciados da física quântica aplicados à química.

${ }^{20}$ Félix Rawitscher nasceu em Frankfurt a.M. em 1890 e estudou ciências naturais em Bonn, Freiburg e Genebra. Em 1912 doutorou-se com a tese "Sexualidade nas ustilagináceas". Estudou fisiologia vegetal em Leipzig com Wilhelm Pfeffer e em 1914 tornou-se assistente do professor Oltmann, um especialista em algas, com quem desenvolveu 
trabalhos sobre esses seres. Foi recrutado para lutar na Primeira Guerra, na qual feriu-se gravemente e foi ainda aprisionado pelos franceses. Em 1921, apresentou tese de livre-docência, mais uma vez tratando das ustilagináceas. Em 1927 foi nomeado professor de botânica florestal na Escola de Silvicultura em Baden, no mesmo ano em que veio a lume sua obra "Die heimische Pflanzenwelt". De acordo com AUST (1964, p. 204), Rawitscher aceitou de imediato o convite de Theodoro Ramos para assumir a cadeira de botânica na USP. Em São Paulo ele se dedicou à organização do Instituto de Botânica, primeiramente, acomodado nas instalações da Faculdade de Medicina, depois, na Alameda Glette e, finalmente, transplantado para a cidade universitária. Sentindo falta de um manual adequado para ensinar botânica no Brasil, Rawitscher escreveu "Introdução ao Estudo da Botânica", que teve várias edições. Ele pesquisou sobretudo a ecologia das plantas brasileiras. Com Mercedes Rachid e Mário Guimarães Ferri deu início às investigações sobre os solos e o padrão de crescimento das plantas do cerrado brasileiro. De acordo com Ferri, uma das principais contribuições de Rawitscher foi ter chamado a atenção para a importância da investigação da economia de água nos estudos de ecologia das plantas. Devido aos numerosos estudos sobre ecologia brasileira, Rawitscher foi nomeado pela UNESCO para compor o "International Committee for Tropical Ecology". Vítima de um ataque cardíaco em 1952, Rawitscher retornou à Alemanha, onde faleceu cinco anos depois. Sobre Rawitscher ver FERRI, 1955; AUST, 1964, p. 204-6; MORRETES, 1994; O ESTADO DE SÃO PAULO, 05 jan 1958.

${ }^{21}$ Inicialmente, o Departamento Cultural contou com outras três divisões além da encarregada de coordenação do intercâmbio científico e difusão de literatura: uma, dedicada a questões relacionadas à imigração, política sanitária e hospitais no exterior, igrejas e ajuda humanitária; uma, voltada às escolas alemãs no estrangeiro, ao reconhecimento acadêmico e visitas de intelectuais, e outra, responsável por assuntos referentes às artes, como música e teatro, exposições e esportes. A partir de 1923, a chancelaria passou a contar com um departamento de imprensa responsável por trabalhos de cunho mais propagandístico, como a difusão de livros, brochuras e impressos. Essa divisão de tarefas estava fundada na ideia de que a Divisão Cultural deveria ter espaço livre para se entregar exclusivamente à política cultural, de caráter mais sutil e com objetivos de mais longo prazo do que as atividades de propaganda. Em 1926, a Divisão Cultural sofreu uma reforma em que foi criada uma subdivisão que concentrou a coordenação dos diversos aspectos relativos às relações científicas internacionais, estrutura que se manteve praticamente inalterada até 1936 (DÜWELL, 1976, p. 90-98).

${ }^{22}$ Politisches Archiv des Auswärtigen Amtes, daqui por diante, PAAA, Akte 61171 Theodoro Ramos a Ernst Bresslau em 15.05.1934 (cópia).

${ }^{23}$ PAAA 61171 Ofício da Embaixada Brasileira de Roma a Theodoro Ramos de 14.05.1934 (cópia).

${ }^{24}$ PAAA 61171. Ernst Bresslau ao Ministério das Relações Exteriores em 22.05.1934.

${ }^{25}$ Segundo Saul Friedländer (2012, p. 103), "as dificuldades materiais relativas à imigração eram consideráveis, sobretudo numa época de incertezas econômicas; ela envolvia uma pesada perda material imediata: as propriedades dos judeus eram vendidas a preços cada vez mais baixos e a taxa para emigração era proibitiva [...] Embora quisessem se livrar dos judeus da Alemanha, os nazistas estavam decididos a expropriá-los primeiro."

${ }^{26}$ PAAA 61171 Deutsches Generalkonsulat an Auswärtiges Amt em 27.07.1934.

${ }^{27}$ PAAA 61171 Ministerium für Wissenschaft, Kunst und Völksbildung an Auswärtigen Amt em 19.10.1934.

${ }^{28}$ PAAA 61171. Cópia da carta de gez. Bachér ao Ministério das Relações Exteriores em 13.09.1934 (grifos no original)

${ }^{29}$ PAAA 65577 Deutsches Generalkonsulat São Paulo em 16.10.1934.

${ }^{30}$ PAAA 65577. Ernst Bresslau ao Ministério das Relações Exteriores em 01.10.1934. Ernst Bresslau ao Departamento Estadual de Finanças de 14.10.1934.

${ }^{31}$ PAAA 65577 Ernst Bresslau ao Presidente do Departamento Estadual de Finanças em 14.10.1934 (grifos no original).

${ }^{32}$ PAAA 65577 Ernst Bresslau ao Presidente do Departamento Estadual de Finanças em 14.10.1934.

${ }^{33}$ PAAA 65577 Frau L. Bresslau-Hoff ao Ministério das Relações Exteriores em 07.12.1934.

${ }^{34}$ PAAA 65577 Ernst Bresslau ao Ministério das Relações Exteriores em 01.05.1934

${ }^{35}$ PAAA 65577 Carl Zeiss a Martin Spahn em 31.12.1934; Carl Zeiss a Ernst Bresslau em 07.01.1935.

${ }^{36}$ PAAA 65577 Rascunho gez Oster em 21.12.1934. Oster usa a expressão "Platzhalter", algo como "guardador de lugar".

${ }^{37}$ PAAA 65577 Ministério da Ciência, Educação e Artes ao Ministério das Relações Exteriores em 16.01.1935.

${ }^{38}$ PAAA 65577 Anexos à carta de Luise Bresslau ao Departamento Estadual de Finanças de 15.05.1935 - "Professor

Dr. Ernst Bresslau", O Estado de São Paulo, 10.05.1935; "Assembléa Constituinte do Estado", O Estado de São Paulo, 11.05.1935.

${ }^{39}$ PAAA 65577 Frau Luise Bresslau ao Ministério das Relações Exteriores em 15.05.1935.

${ }^{40}$ PAAA 61171 Deutsches Generalkonsulat ao Ministério das Relações Exteriores em 21.05.1935.

${ }^{41}$ A Auslandsorganisation (A.O. - Organização Estrangeira do Partido Nazista) foi formada em 1931, encarregada de coordenar as filiais do Partido Nazista no estrangeiro. Seu diretor foi Ernst Wilhelm von Bohle que, de acordo com Dietrich $(2007 \mathrm{~b}, \mathrm{p}$.), ocupava o terceiro escalão na hierarquia do Reich, assumindo posição análoga à de Joseph Goebbels, ministro da Propaganda. Com a ascensão ao poder em 1933, a A.O. ampliou seu raio de ação, que alcançou o Brasil e outros países da América do Sul. Visava a atingir os nascidos na Alemanha que viviam no exterior, de modo a 
torná-los pontos de apoio das investidas de propaganda cultural e da diplomacia, levá-los a contribuir com recursos para o Partido e fornecer informações comerciais. A respeito da estrutura da A.O, suas atribuições e papel na coordenação das filiais do Partido Nazista no Brasil, ver MORAES, 1996; MAGALHÃES, 1998 e DIETRICH, 2007, 2007 b.

${ }^{42}$ PAAA 61171 Deutsches Generalkonsulat ao Ministério das Relações Exteriores em 15.08.1935.

${ }^{43}$ PAAA 61171 Anton Koegel ao Ministério das Relações Exteriores de 31.05.1935.

${ }^{44}$ Carta de Otto Hecht a Rocha Lima de 05.04.1933. Fundo Rocha Lima, Centro de Memória do Instituto Biológico de São Paulo.

${ }^{45}$ Carta de Martin Mayer a Rocha Lima de 04.07.1935. Fundo Rocha Lima, Centro de Memória do Instituto Biológico de São Paulo.

${ }^{46}$ Von Ubisch nasceu em Swinemünde em 1886. Estudou zoologia nas Universidades de Freiburg e Rostock, onde se doutorou em 1912, tornando-se livre-docente em 1919. Foi nomeado catedrático de zoologia e anatomia comparada da Universidade de Münster em 1927, período em que se dedicou aos estudos sobre embriologia e físiologia do desenvolvimento. Filho de mãe judia, não pôde ser diretamente aposentado pelos nazistas com a Lei da Restauração do Funcionalismo Público por ter servido na Primeira Guerra, mas em 1935 foi demitido em decorrência da promulgação das "Leis de Nuremberg". Emigrou para a Noruega, mas a invasão do país pelas tropas de Hitler levou-o a se estabelecer em Los Angeles. Terminada a Guerra, von Ubisch retornou ao Instituto de Biologia Marinha de Bergen, na Noruega e também permaneceu por uma temporada nas estações zoológicas de Nápoles e Helgolândia. Ver DEICHMANN, 1996.

${ }^{47}$ PAAA 61171 Deutsches Generalkonsulat ao Ministério das Relações Exteriores em 11.09.1935. O cônsul alemão faz ressoar aqui a associação bastante corrente que se fazia entre os judeus e maçons, ambos considerados inimigos em potencial da Alemanha nazista. Devido ao caráter internacionalista e secreto de suas atividades, os maçons foram alvo de desconfiança por parte do Terceiro Reich. Junto com os comunistas e judeus, eles utilizariam suas redes internacionais para conspirar contra a Alemanha. Esse discurso, veiculado pela propaganda oficial do regime, legitimou medidas como a prisão e perseguição de maçons e apropriação de lojas maçônicas. Um dos departamentos da Gestapo ficou responsável pela supervisão de indivíduos ligados à maçonaria. Em janeiro de 1933, todos os maçons membros do Partido Nazista foram expulsos, pois suas inclinações humanitárias não os tornavam aliados de confiança nos esforços de coordenação (Gleichschaltung) e arianização. Sobre a maçonaria na Alemanha nazista, ver NEUBERGER, 1980.

${ }^{48}$ Já durante a aplicação da Lei do Funcionalismo Público, de abril de 1933, os nazistas depararam-se com a dificuldade de definir o que entendiam como "origem não-ariana". "Não-ariano" seria todo aquele que tivesse um ou mais judeus entre os pais ou avós, os quais eram qualificados a partir do pertencimento à religião judaica. Com as leis de Nuremberg, ficou definido que judeu seria todo aquele que tivesse pelo menos três avós judeus, independentemente de sua ligação com a comunidade judaica ou de confissão religiosa. Este era o chamado "Volljuden". "Halbjuden" foi a categoria empregada para designar pessoas com dois avós judeus, ao passo que aquelas que tinham apenas um dos avós judeu foram designadas "Vierteljuden" (SCHPUN, 2011, p. 75-7; BENZ, 2001, 2011). Schpun (2011, p. 77) assinala a contradição em definir os ancestrais dos indivíduos considerados judeus a partir de critérios religiosos. "E com essa definição, nenhum critério biológico ou fenotípico apareceu (tipo sanguíneo, corpulência, cor do cabelo, forma do rosto, do nariz, etc.), apesar de terem povoado textos, panfletos e desenhos de propaganda antissemita".

${ }^{49}$ PAAA 61171 Ministério da Ciência, Educação e Formação Popular ao Ministério das Relações Exteriores em 28.09.1935.

${ }^{50}$ PAAA 61171 Organização Estrangeira do Partido Nacional-Socialista Alemão ao Ministério das Relações Exteriores em 10.10.1935.

${ }^{51}$ PAAA 61171 Deutsches Generalkonsulat ao Ministério das Relações Exteriores em 18.10.1935. Richard Goldschmidt, nascido em 1878 em Frankfurt am Main e formado pela Universidade de Heidelberg em 1896, começou sua trajetória com o estudo do desenvolvimento e do sistema nervoso de vermes, tendo trabalhado com o renomado Richard Hertwig. Em 1906 tornou-se professor da Universidade de Munique, quando iniciou suas pesquisas sobre genética. Seu principal interesse era pelos mecanismos de determinação sexual, os quais investigou na chamada "mariposa cigana" ou lagarta-do-sobreiro (gypsy moth). A repercussão dos estudos de Goldschmidt levou-o, em 1914, à direção do recém-fundado Instituto Kaiser-Wilhelm de Biologia, no qual prosseguiu as pesquisas sobre genética, com foco nas mutações. Devido à origem judia, Goldschmidt teve de deixar a Alemanha em 1935. Estabeleceu-se na Califórnia, onde, em 1940, publicou o influente "The Material Basis of Evolution", em que defendeu que a evolução devia-se ao acúmulo de pequenas e constantes mudanças. Formulou a hipótese de que grandes mutações que originavam mutantes (que ele chamou de "monstros") poderiam surgir de uma geração e, por garantirem vantagem na seleção natural, acabavam por prevalecer. Ver a esse respeito DIETRICH, 2003.

${ }^{52}$ PAAA 61171 Ministério da Ciência, Educação e Formação Popular ao Ministério das Relações Exteriores em 11.11.1935.

${ }^{53}$ PAAA 61171 Ministério da Ciência, Educação e Formação Popular ao Ministério das Relações Exteriores em 18.02.1936. Ministério das Relações Exteriores ao Deutsches Generalkonsulat em 20.02.1936.

${ }^{54}$ PAAA 61171 Organização Estrangeira do Partido Nacional Socialista Alemão ao Ministério das Relações Exteriores

${ }^{55}$ MORAES, 1996; DIETRICH, 2007b. 
${ }^{56}$ Nascido em Berlim em 1893, Ernst Marcus publicou seu primeiro trabalho em zoologia em 1914, quando se alistou como voluntário para lutar na Primeira Guerra. Pertencia ao Instituto de Zoologia da Universidade de Berlim quando veio a lume o segundo trabalho, em 1919. Ali foi bastante influenciado pela Mecânica do Desenvolvimento (Entwicklungsmechanik), cujo interesse foi despertado pelo zoólogo Heider, com quem conviveu na universidade. Casou-se com Eveline Du Bois Reymond, neta do grande fisiologista Emil Du Bois Reymond. Juntos, Ernst e Eveline realizaram uma série de investigações zoológicas sobre os mais diferentes grupos de animais. Em 1933, Marcus publicou Geografia animal (Tiergeographie), ano em que foi obrigado a deixar o cargo em Berlim, vindo a aceitar o convite feito pela Universidade de São Paulo. Nos 37 anos em que lecionou nesta universidade, formou uma legião de discípulos e fez investigações sobre diversos grupos de animais sob o ponto de vista sistemático, zoogeográfico, anatômico, embriológico e ecológico. Faleceu na capital paulista em 30 de junho de 1968 (MENDES, 1994).

${ }^{57}$ Sobre a criação e trajetória da Faculdade de Medicina de São Paulo, ver MARINHO, 1993 e MARINHO; MOTA, 2012.

${ }_{58}^{58}$ Sobre a Escola Paulista de Medicina, ver SILVA, 2003.

${ }^{59}$ Em carta de 06 de julho de 1933, Rocha Lima escreveu a Octavio de Carvalho: "Ao concordar após justificada relutância com a inclusão de meu nome entre os fundadores da Escola Paulista de Medicina e depois entre os membros de seu conselho consultivo tinha eu ao menos a esperança de poder por qualquer forma auxiliar eficazmente um grupo de colegas dos mais distintos empenhados em meritória obra, que me parece digna de todo apoio e simpatia. Verifico porém com pesar que os meus múltiplos deveres como diretor do Instituto Biológico me impossibilitam completamente de tomar parte ativa e útil nos trabalhos que requer a realização dessa obra, cujo sucesso já se acha garantido.” Rocha Lima a Octavio de Carvalho em 06.07.1933. Arquivo Rocha Lima, Centro de Memória do Instituto Biológico de São Paulo.

${ }^{60}$ Martin Ficker nasceu em Sohland no Spree em 17 de novembro de 1868. Formou-se em medicina pela Universidade de Bresslau, onde foi assistente de Karl Flügges no Instituto de Higiene. Dedicou-se, à época, ao ramo da pesquisa bacteriológica do ar. Entre 1896 e 1901 foi assistente de F. Hoffmann no Instituto de Higiene de Leipzig, onde defendeu livre-docência em 1898 sobre o tema "Sobre o tempo de vida e morte de germes patogênicos". Em 1902 tornou-se diretor de departamento do Instituto de Higiene da Universidade de Berlim e no ano seguinte foi nomeado professor de higiene desta universidade. Publicou o "Manual de Higiene" com seus professores Max Rubner e Gruber, entre os anos de 1911-1923. Em 1913 foi nomeado diretor do Instituto Bacteriológico de São Paulo. Em virtude da Guerra, retornou em 1917 à Alemanha, quando assumiu o posto de diretor de departamento na Sociedade Kaiser Wilhelm, ocasião na qual realizou estudos sobre a toxina do antraz. Retornou a São Paulo em 1923, onde fundou um laboratório de bacteriologia que permaneceu ligado à Sociedade Kaiser Wilhelm e foi elevado à categoria de estação microbiológica da Sociedade Kaiser Wilhelm. Permaneceu aí até sua morte, em 22 de novembro de 1950. Durante esse período, realizou pesquisas sobre lepra, febre tifoide, disenteria, entre outras doenças. JUSATZ, 1961.

${ }^{61}$ PAAA 63965 Carta de Octavio de Carvalho a Walter Büngeler de 19.12.1935.

${ }^{62}$ PAAA 63965 Martin Ficker ao Deutsches Generalkonsulat em 26.12.1935.

${ }^{63}$ PAAA 63965 Martin Ficker ao Deutsches Generalkonsulat em 26.12.1935.

${ }^{64}$ PAAA 63965 Carta de Octavio de Carvalho a Walter Büngeler de 07.01.1936.

${ }^{65}$ PAAA 63965 Carta de Walter Büngeler a Octavio de Carvalho de 30.01.1936.

${ }^{66}$ PAAA 63965 Carta de Walter Büngeler a Octavio de Carvalho em 30.01.1936; Walter Büngeler ao Ministério das Relações Exteriores em 13.03.1936.

${ }^{67}$ PAAA 63965 Carta de Octavio de Carvalho a Walter Büngeler em19.02.1936.

${ }^{68}$ PAAA 63965 Ministério da Ciência, Educação e Formação Popular ao Ministério das Relações Exteriores em 18.02.1936.

${ }^{69}$ PAAA 63965 Consulado Alemão de Danzig ao Ministério das Relações Exteriores em 20.01.1936.

${ }^{70}$ PAAA 63965 Ministério das Relações Exteriores ao Consulado Alemão de Danzig em 24.04.1936.

${ }^{71}$ PAAA 63965 Walter Büngeler ao Ministério da Ciência, Educação e Formação Popular em 20.04.1936; Walter Büngeler ao Consulado Alemão de Danzig em 09.05.1936.

${ }^{72}$ PAAA 63965 Walter Büngeler ao Consulado Alemão de Danzig em 09.05.1936.

${ }^{73}$ PAAA 63965 Carta de Henrique da Rocha Lima a Walter Büngeler de 03.06.1936.

${ }^{74}$ PAAA 63965 Carta de Martin Ficker a Walter Büngeler de 01.06.1936 (cópia).

${ }^{75}$ PAAA 63965 Carta do Consulado Geral de São Paulo ao Ministério das Relações Exteriores de 08.06.1936.

${ }^{77}$ PAAA 63965 Octavio de Carvalho a Walter Büngeler em 02.06.1936 (cópia).

${ }^{77}$ PAAA 63965 Walter Büngeler ao Ministério das Relações Exteriores em 16.06.1936.

${ }^{78}$ PAAA 63965 Octavio de Carvalho a Volhard em 02.06 .1936 (cópia).

${ }^{79}$ PAAA 65577 Büngeler, Walter. Bericht an das Auswärtige Amt und das Reichs- und Preussische Kulturministerium Berlim, 09.12.1936.

${ }^{80}$ De acordo com Lessa, a expansão de filiais da Aliança Francesa iniciou-se logo em seguida a sua criação, em 1884. No Brasil, a filial do Rio de Janeiro foi estabelecida em 1891. As principais medidas da política cultural francesa para a América Latina passaram pelo Groupement des Universités et Grandes Écoles de France pour le Relations avec l'Amerique Latine, fundado em 1907 e ligado ao Service des Oeuvres, órgão do Ministério das Relações Exteriores. 
Durante a Primeira Guerra, o intercâmbio intelectual fomentado pelo "Groupement" sofreu abalos, mas nos anos 1920 tornou-se novamente intenso. Em 1922 foi fundado no Rio de Janeiro o Instituto Franco-Brasileiro de Alta Cultura, responsável por coordenar as relações culturais franco-brasileiras nos anos seguintes (LESSA 1994).

Recebido em abril/2013.

Aprovado em maio/2013. 